\title{
ПЕТРОЛОГИЯ, ГЕОХИМИЯ
}

\section{ГЕОХИМИЯ, ВОЗРАСТ И ГЕОДИНАМИЧЕСКИЕ ОБСТАНОВКИ ФОРМИРОВАНИЯ САУРСКОЙ ГАББРО-ГРАНИТОИДНОЙ ИНТРУЗИВНОЙ СЕРИИ (ВОСТОЧНЫЙ КАЗАХСТАН)}

\author{
С.В. Хромых ${ }^{1,2}$, П.Д. Котлер ${ }^{1,2}$, Д.В. Семенова ${ }^{1}$ \\ ${ }^{1}$ Институт геологии и минералогии им. В.С. Соболева СО РАН, Новосибирск \\ ${ }^{2}$ Новосибирский государственный университет, Новосибирск
}

Изложены результаты геохимических и геохронологических исследований габбро, гранитов и базитовых даек Жарма-Саурской зоны, Восточный Казахстан. Установлено, что габбро-диорит-гранитоидная саурская интрузивная серия сформировалась 330-327 млн л. н. в геодинамической обстановке субдукции под новообразованную континентальную окраину Казахстанского континента. Габбро и диориты образованы при эволюции базитовых магм, возникших в результате частичного плавления обводненной деплетированной мантии над зоной субдукции; гранитоиды - при частичном плавлении вулканогенно-осадочных субстратов под воздействием базитовых магм.

Впервые определены возраст и геохимические особенности даек северо-восточного простирания в Жарма-Саурской зоне. Они имеют среднекарбоновый возраст (315 млн лет) и проявились в результате разрывов сплошности литосферы орогенного сооружения при сдвиговых движениях по глубинным разломам. Базитовые дайки характеризуются относительно обогащенным геохимическим составом, что свидетельствует о другом мантийном источнике.

Ключевые слова: габбро-гранитные интрузивные серии, аккреционно-коллизионные системы, Восточный Казахстан, Центральная Азия.

Распространенным индикатором процессов мантийно-корового взаимодействия являются габброгранитоидные интрузивные серии, проявляющиеся в различных геодинамических обстановках [Кузнецов, 1964; Фролова, Бурикова, 1997; Короновский, Демина, 2011; Владимиров и др., 2013]. Преимущественно они проявлены на конвергентных границах типа «океан - континент», но встречаются и в коллизионных, внутриплитных и рифтогенных обстановках. Соотношения базитовых и кремнекислых членов серий, последовательность и этапность их формирования, особенности состава пород в совокупности позволяют установить главные закономерности мантийно-корового взаимодействия в том или ином сегменте земной коры. Особенно актуальным является решение этой проблемы для внутриконтинентальных складчатых поясов, сформированных при аккреционно-коллизионных взаимодействиях континентов и террейнов различной природы и закрытии палеоокеанических пространств.

\section{Геологическая позиция}

Одним из крупнейших внутриконтинентальных аккреционно-коллизионных поясов является Центрально-Азиатский складчатый пояс, сформированный в течение фанерозоя при закрытии Палеоазиатского океана. Исследования ультрабазит-базитовых и сопряженных гранитоидных ассоциаций палеозой- ского возраста в его пределах позволили обосновать важную роль активности мантии и мантийнокорового взаимодействия в процессах эволюции литосферы и формирования континентальной коры [Ярмолюк, Коваленко, 2003; Ярмолюк и др., 2011; Владимиров и др., 2013; Крук, 2015 и др.].

Эволюция структур Центрально-Азиатского складчатого пояса завершилась в основном в позднем палеозое с формированием нескольких герцинских складчатых систем, протягивающихся вдоль южной окраины Сибирского континента [Зоненшайн и др., 1990; Хаин, 2001; Windley et al., 2007]. Одной из них является ОбьЗайсан-Гобийская складчатая система, возникшая на юго-западном фланге Сибирского континента. Ее частью является Алтайская аккреционно-коллизионная система (рис. 1, врезка), возникшая в позднем палеозое при взаимодействии Сибирского и Казахстанского континентов [Зоненшайн и др., 1990; Хаин, 2001; Владимиров и др., 2003; 2008]. В истории ее развития можно выделить несколько стадий - от субдукционной до аккреционно-коллизионной и внутриплитной, каждая из которых охарактеризована определенным стилем тектонических движений, набором осадочных формаций и проявлениями различного магматизма. В результате событий на территории современного Восточного Казахстана были совмещены структурновещественные комплексы разной геодинамической природы. Жарма-Саурская зона (рис. 1) расположена в юго-западной части Алтайской коллизионной системы 
и представляет собой область сочленения герцинских окраинно-морских и океанических структурновещественных комплексов с каледонскими образованиями окраины Казахстанского палеоконтинента [Ермолов и др., 1977; Щерба и др., 1998]. Эта окраинноконтинентальная зона известна как ЧингизТарбагатайская, она является восточным сегментом крупной Чингиз-Северо-Тяньшанской островодужной системы энсиалической природы, заложенной в раннем палеозое [Дегтярев, 2012]. Процессы субдукции литосферы Обь-Зайсанского бассейна под ЧингизТарбагатайскую окраину Казахстанского континента происходили с начала среднего палеозоя, в силуре и раннем девоне здесь существовала активная континентальная окраина с проявлениями гранитоидного магматизма и развитием кислого вулканизма.

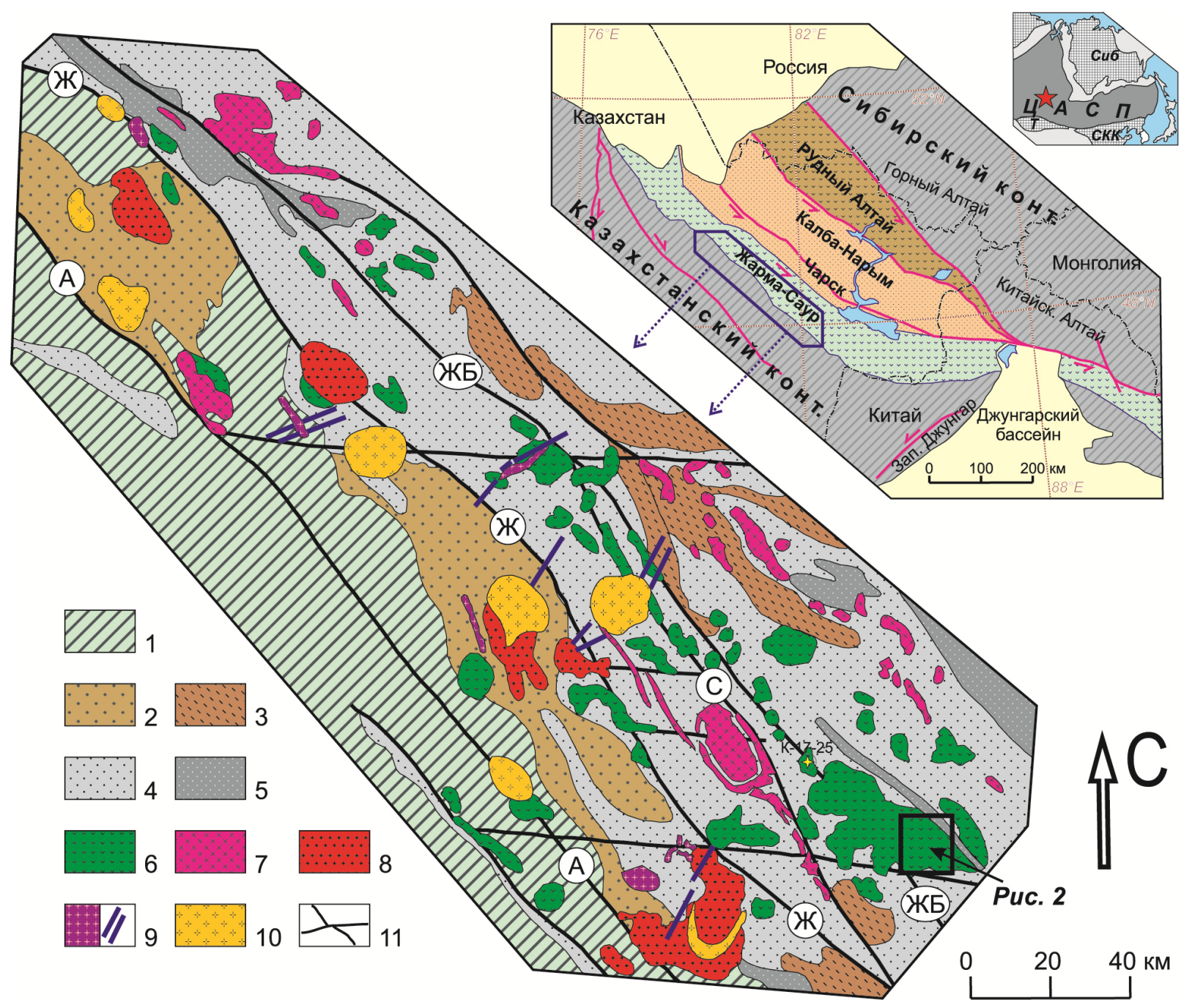

Рис. 1. Тектоно-магматическая схема зоны сочленения Зайсанской

и Чингиз-Тарбагатайской складчатых областей (по Ермолов и др., 1977)

1 - кембрийско-ордовикские осадочно-вулканогенные комплексы Восточно-Чингизской зоны; 2 - силурийско-девонские осадочные, вулканогенные и интрузивные комплексы Восточно-Чингизской зоны; 3 - осадочные и вулканогенные отложения $\mathrm{D}_{2} \mathrm{gv}-\mathrm{D}_{3} \mathrm{fr} ; 4$ - осадочные и вулканогенные отложения $\mathrm{C}_{1} \mathrm{t}_{2}-\mathrm{v}_{1} ; 5$ - преимущественно вулканогенные формации $\mathrm{C}_{2-3} ; 6-10-$ герцинские габбро-гранитные серии и гранитные комплексы: 6 - саурская габбро-диорит-тоналитовая серия, 7 - салдырминская габбро-гранодиорит-гранитная серия, 8 - жарминская габбро-гранитная серия, 9 - керегетас-эспинский комплекс щелочных гранитов гранит-порфиров (массивы и дайковые пояса), 10 - кандыгатайский и каракольский комплексы лейкократовых гранитов; 11 - разломы (Ж - Жарминский, А - Аркалыкский, ЖБ - Жанан-Бугазский, С - Сиректасский).

На врезке показано районирование Алтайской коллизионной системы герцинид и положение региона исследований

Fig. 1. Tectonic map of magmatic associations in joint area of Zaisan and Chingiz-Tarbagatai fold belts (according to Ermolov et al., 1977)

1 - Cambrian-Ordovician sediments and volcanites in Eastern-Chingiz zone; 2 - Silurian-Devonian sediments, volcanites and intrusions in Eastern-Chingiz zone; 3 - sediments and volcanites of $\mathrm{D}_{2} \mathrm{gv}-\mathrm{D}_{3}$ fr age; 4 - sediments and volcanites of $\mathrm{C}_{1} \mathrm{t}_{2}-\mathrm{v}_{1}$ age; $5-$ volcanites of $\mathrm{C}_{2-3}$ age; 6-10 - Hercynian gabbro-granite series and granite complexes: 6 - Saur gabbro-granite series, 7 - Saldyrma gabbrogranodiorite-granite series, 8 - Zharma gabbro-granite series, 9 - Keregetas-Espe complex of alkali granites (massifs and dikes), 10 Kandygatai and Karakuls complexes of leucocratic granites; 11 - faults (Ж - Zharma, A - Arkalyk, ЖБ - Zhanan-Bugaz, C - Sirektas). Inset shows main zones of Altai collision system and position of investigated area 
Центральной тектонической структурой ЖармаСаурской зоны является Калба-Чингизский (по [Тектоническая... 1963]) или Жарминский (по [Ермолов и др., 1977]) глубинный разлом, по которому проходит сочленение каледонских и герцинских структур (рис. 1). Западная часть области сочленения известна как Восточно-Чингизская зона, в строении которой участвуют четыре структурных этажа: раннекембрийский, позднекембрийский-позднеордовикский, силурийско-девонский, позднедевонско-каменноугольный. Общая мощность каледонских формаций превышает 20 км. В раннегерцинский период зона представляла собой относительно устойчивую область, характеризовавшуюся субплатформенным осадконакоплением. Для этого периода характерны известняковая $\left(\mathrm{D}_{3} \mathrm{fm}\right)$ и карбонатно-терригенная угленосная $\left(\mathrm{C}_{1} \mathrm{t}-\mathrm{v}_{1}\right)$ формации.

Восточная часть области сочленения обозначена как Жарминская [Ермолов и др., 1977] структурноформационная зона, в ее строении выделяются три структурных этажа: средне-верхнедевонский, раннекаменноугольный, средне-позднекаменноугольный. Ранние осадки на юго-западе имеют признаки прибрежно-морских условий и выделяются в гравелитопесчано-сланцевую формацию $\left(\mathrm{D}_{2} \mathrm{gv}-\mathrm{D}_{3} \mathrm{fr}\right)$, на северо-востоке одновозрастные образования имеют морской генезис и выделяются в кремнисто-андезибазальтовую формацию $\left(\mathrm{D}_{2} \mathrm{gv}-\mathrm{D}_{3} \mathrm{fr}\right)$. Раннекаменноугольные отложения также неоднородны по латерали: на северо-востоке залегает кремнисто-андезитовая формация $\left(\mathrm{C}_{1} \mathrm{t}_{2}-\mathrm{v}_{1}\right)$ океанической природы, на юго-западе одновозрастные с ней отложения принадлежат песчано-сланцевой формации окраинноконтинентальной природы. Различия в строении разрезов Жарминской зоны позволили расчленить ее на две структурно-формационные подзоны (Кояндино-Аркалыкскую на северо-востоке и Жарминскую на юго-западе), разграниченные Жанан-Бугазским глубинным разломом. Верхний структурный этаж сложен вулканогенными формациями: дацитомолассовой $\left(\mathrm{C}_{2}\right)$, трахибазальт-трахиандезитовой $\left(\mathrm{C}_{2-3}\right)$ и дацито-липаритовой $\left(\mathrm{C}_{3}\right)$. Они выполняют прогибы и мульды, наследующие общий структурный план или наложенные на ранее сформированные антиклинории и синклинории. Общая мощность разреза Жарминской зоны превышает 7 км.

В связи с закрытием Обь-Зайсанского океанического бассейна и началом формирования Алтайской коллизионной системы герцинид, на рубеже раннего и среднего карбона Жарма-Саурская зона испытала тектоно-магматическую активизацию. Как в Восточно-Чингизской, так и в Жарминской зонах был проявлен наземный вулканизм, а главным индикатором эндогенной активности явилось формирование крупного Жарминского интрузивного пояса, который протягивается вдоль Жарминского глубинного разлома в северо-западном направлении более чем на 400 км при ширине 50-80 км (см. рис. 1). Детальные геологические, минералогические и петрологические исследования интрузивного магматизма этого района проведены в 1960-1970-х гг. под руководством П.В. Ермолова [Ермолов и др., 1977]. Было выделено несколько габброидных, габбро-гранитоидных, гранитоидных серий, комплексов, вулканоплутонических ассоциаций. Общая продолжительность интрузивного магматизма была оценена с конца раннего карбона (саурская серия $\mathrm{C}_{1} \mathrm{n}$ ) до поздней перми - триаса (несколько габбро-гранитных и гранит-лейкогранитных комплексов).

Наиболее широкое распространение среди интрузивных образований Жарма-Саурской зоны имеет саурская габбро-диорит-тоналитовая интрузивная серия. Площадь развития интрузивов саурской серии превышает 20 тыс. км², наиболее крупные интрузивы и максимальная их сосредоточенность отмечаются в юго-восточной части. Исторически с 40-50-х гг. $\mathrm{XX}$ в. породы серии были объединены в единый саурский комплекс, а многообразие пород объяснялось процессами ассимиляции. При детальном картировании установлено, что саурский комплекс имеет сложную историю формирования, а ранние и поздние его фазы разделены особым комплексом даек. Это позволило относившиеся ранее к фазам группы пород выделить в многофазные комплексы, а совокупность последних рассматривать как многоритмичную интрузивную серию. Были выделены следующие комплексы пород [Ермолов и др., 1977]:

1) саурский габбро-диорит-плагиогранитовый комплекс (фазы: 1 - габбронориты и оливиновые габбро, 2 - габбро и амфиболовые габбро, 3 - диориты, 4 - кварцевые диориты и тоналиты, 5 - трондьемиты и плагиограниты);

2) комплекс «межгранитовых» даек диоритовых порфиритов, микродиоритов, плагиогранитпорфиров;

3) бугазский тоналит-гранитовый комплекс (фазы: 1 - тоналиты и трондьемиты, 2 - биотитовые адамеллиты и граниты, 3 - жильные граниты и аплиты);

4) комплекс послегранитовых даек (1 - тоналитпорфиры и граносиенит-порфиры, 2 - диоритовые порфириты, диабазы и спессартиты, 3 - аплитовидные граниты и кварцевые порфиры).

Детальное описание геологической позиции, петрографии, минералогии и петрохимии интрузивных пород серии дано П.В. Ермоловым с соавт. [1977]. Были сделаны предположения, что мафические породы серии произошли из магмы, близкой по составу к высокоглиноземистым базальтам, и сформированы при плавлении обводненной мантии; гранитоидные породы как саурского, так и бугазского комплексов рассмотрены как результат плавления корового вещества под воздействием базитовых магм, 
при этом бугазский комплекс выделен как самостоятельный ритм глубинной магматической активности. Аналогично как самостоятельные ритмы эндогенной активности описаны комплексы базит-гранитовых даек.

В последние десятилетия получили широкое развитие новые прецизионные методы исследования вещества, произошла смена глобальной геодинамической парадигмы, появилось множество новых моделей эволюции внутриконтинентальных складчатых поясов с позиций теории тектоники литосферных плит и теории мантийных плюмов. В связи с этим исследования состава, возраста и геодинамических обстановок формирования саурской серии вновь представляются актуальными. Мы провели исследования некоторых магматических пород саурской серии геохимическими, изотопными и геохронологическими методами, что позволило уточнить время, состав источников и геодинамическую обстановку формирования с современных геодинамических позиций.

\section{Фактический материал и методы исследования}

Нами были изучены Бугазский и южная часть Чангского массивов (по [Ермолов и др., 1977]), расположенные в юго-западной части листа M-44-XXXV Государственной геологической карты СССР (рис. 2). В этом районе, по данным государственного геологического картирования, габброидные и гранитоидные породы прорывают с ороговикованием осадочные и вулканогенные толщи девона и раннего карбона. Породы саурского комплекса представлены габбро и диоритами. Габбро слагают тело размером $2 \times 3$ км, образующее массив горы Улькенлаба; большинство базитовых пород представлено диоритами и кварцевыми диоритами, слагающими несколько более крупных интрузий. Гранитоиды прорывают габбро и диориты и слагают крупный Бугазский массив. В районе закартированы две системы базитовых и гранитоидных даек: ранняя субмеридионального и северо-западного простирания и поздняя - северо-восточного простирания. Дайки базитового состава представлены долеритами, долеритовыми порфиритами, диоритовыми порфиритами; дайки кислого состава - гранит-порфирами, граносиенит-порфирами и аплитами. Дайки имеют мощность от десятков сантиметров до первых метров, наиболее крупные дайки протягиваются на несколько километров. Их внутреннее строение обычно простое, однофазное, иногда наблюдается дифференциация по зернистости пород от центра к краю даек.

Для наших исследований были выбраны образцы габбро, гранитов и базитовых даек (см. местоположение на рис. 2). Несколько проб было специально отобрано для выделения цирконовых монофракций с целью изотопного датирования. Проба диоритов саурского комплекса, использованная для геохроно- логических исследований, отобрана из безымянного массива примерно в 25 км к северо-западу от изученного района (см. рис. 1).

Петрографические исследования образцов пород выполнены по прозрачным покрытым шлифам с помощью оптического поляризационного микроскопа Carl Zeiss AxioScope.A1, оснащенного фотокамерой Canon EOS 650D. Определение состава пород выполнено в Центре коллективного пользования многоэлементных и изотопных исследований (ЦКП МИИ) ИГМ СО РАН (г. Новосибирск). Определение содержаний петрогенных компонентов проведено методом рентгенофлуоресцентного анализа с использованием спектрометра ARL-9900 XL; определение концентраций редкоземельных и редких (Rb, $\mathrm{Sr}, \mathrm{Y}, \mathrm{Zr}, \mathrm{Nb}, \mathrm{Cs}, \mathrm{Ba}, \mathrm{Hf}$, $\mathrm{Ta}$, Th, U, Sc, V, Cr, Co, Ni, Cu, Zn) элементов выполнено методом ICP-MS на масс-спектрометре Finnigan Element II по стандартной методике. Sm-Nd изотопные исследования выполнены по валовым пробам пород в Геологическом институте КНЦ РАН (г. Апатиты) на семиканальном твердофазном масс-спектрометре Finnigan-MAT 262 (RPQ). Измерения изотопных отношений проводили в статическом режиме с использованием двухленточных источников ионов. Изотопный состав неодима в процессе измерений нормализовали по отношению к ${ }^{146} \mathrm{Nd} /{ }^{144} \mathrm{Nd}=0,7219$, а затем приводили к значению ${ }^{143} \mathrm{Nd} /{ }^{144} \mathrm{Nd}=0,511860$ в стандарте La Jolla.

Геохронологические исследования выполнены U-Pb изотопным методом по единичным зернам циркона методом LA-SF-ICP-MS на масс-спектрометре высокого разрешения Element XR (Thermo Fisher Scientific) с системой пробоотбора лазерной абляцией UP-213 (New Wave Research) в ЦКП МИИ ИГМ CO РАН (г. Новосибирск), согласно методике, описанной в [Хубанов и др., 2016].

Датирование выполнено по единичным зернам цирконов, для калибровки использованы цирконовые стандарты TEMORA-II и Plešovice. Цирконы облучались импульсным лазерным лучом с частотой 5 Гц, диаметром 25-30 мкм в течение 30 с. Испаренное вещество из лазерной установки в массспектрометр транспортировалось потоком чистого гелия. Коррекция дрейфа сигнала измеряемых изотопов, учет фоновых сигналов, расчет изотопных отношений и их погрешностей выполнены в программе Glitter [Griffin et al., 2008]. Расчет значений возраста методом построения диаграммы с конкордией выполнен с помощью программы ISOPLOT-3 [Ludwig, 2003]. Измерялось четыре изотопных отношения: ${ }^{207} \mathrm{~Pb} /{ }^{206} \mathrm{~Pb}, \quad{ }^{206} \mathrm{~Pb} /{ }^{238} \mathrm{U}, \quad{ }^{207} \mathrm{~Pb} /{ }^{235} \mathrm{U}$ и ${ }^{208} \mathrm{~Pb} /{ }^{232} \mathrm{Th}$. Расчет возраста проводился методом рассмотрения U-Pb $\left({ }^{206} \mathrm{~Pb} /{ }^{238} \mathrm{U}-{ }^{207} \mathrm{~Pb} /{ }^{235} \mathrm{U}\right)$ системы на конкордии. Относительная погрешность измерения изотопного отношения в одной точке $(1 \sigma)$ для ${ }^{206} \mathrm{~Pb} /{ }^{238} \mathrm{U}$ составила $\sim 1,5 \%$, a ${ }^{207} \mathrm{~Pb} /{ }^{235} \mathrm{U} \sim 4-5 \%$ для стандартных цирконов. 


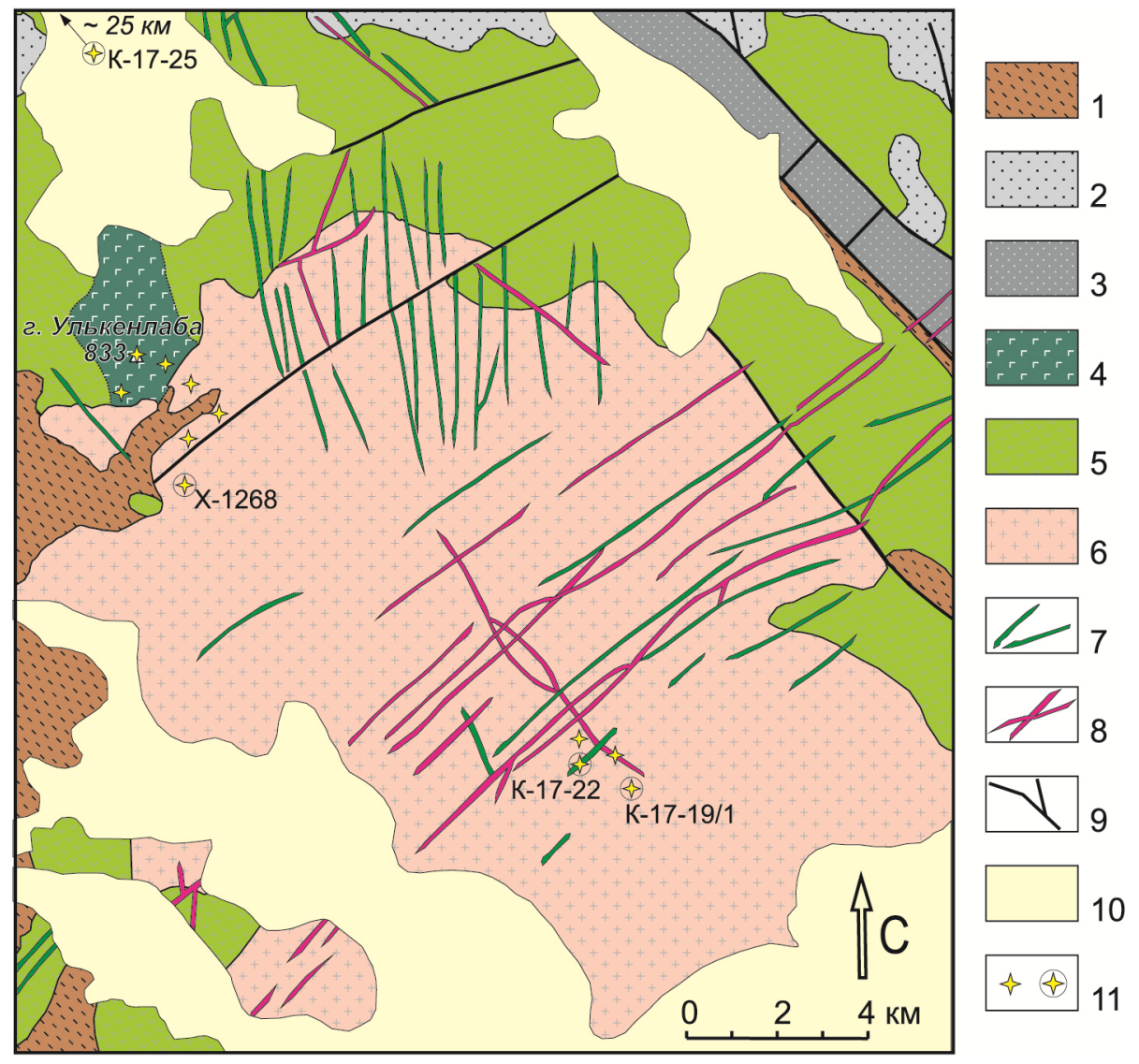

Рис. 2. Геологическое строение Бугазского массива на основе государственной геологической карты СССР масштаба 1 : 200 000, фрагмент листа M-44-XXXV

1 - осадочные и вулканогенные отложения $\mathrm{D}_{2} \mathrm{gv}-\mathrm{D}_{3} \mathrm{fr} ; 2$ - осадочные и вулканогенные отложения $\mathrm{C}_{1} \mathrm{t}_{2}-\mathrm{v}_{1} ; 3$ - осадочные и вулканогенные отложения $\mathrm{C}_{2-3} ; 4$ - габбро и оливиновые габбро саурского комплекса; 5 - габбродиориты, диориты и кварцевые диориты саурского комплекса; 6 - гранитоиды бугазского комплекса; 7 - поздние «постгранитные» дайки базитового состава (долериты, диоритовые порфириты, спессартиты); 8 - поздние «постгранитные» дайки кислого состава (гранит-порфиры, аплиты); 9 - разломы; 10 - рыхлые отложения; 11 - точки наблюдения и отбора проб, описанных в статье; кружками обведены и подписаны пробы, по которым получены U-Pb геохронологические данные

Fig. 2. Geological map of Bugaz massif, based on Geological map of USSR, scale 1:200 000, M-44-XXXV 1 - sediments and volcanites of $\mathrm{D}_{2}$ gv- $\mathrm{D}_{3}$ fr age; 2 - sediments and volcanites of $\mathrm{C}_{1} \mathrm{t}_{2}-\mathrm{v}_{1}$ age; 3 - sediments and volcanites of $\mathrm{C}_{2-3}$ age; 4 - gabbro and $\mathrm{Ol}$ gabbro of Saur complex; 5 - gabbrodiorites, diorites and Qtz diorites of Saur complex; 6 - granites of Bugaz complex; 7 - latest post-granite dikes with mafic composition (dolerites, diorites, spessartites); 8 - latest post-granite dikes with felsic composition (porphyry granites, aplites); 9 - faults; 10 - Quarternary sediments; 11 - points of outcrops and sampling; points in circles are position of samples with $\mathrm{U}-\mathrm{Pb}$ geochronological data

Для двух образцов пород были выполнены исследования Lu-Hf изотопной системы в единичных зернах цирконов. Исследования проведены в Департаменте наук о Земле Университета Гонконга (Китайская Народная Республика) методом лазерной абляции на мультиколлекторном масс-спектрометре с индуктивно-связанной плазмой (LA-MC-ICPMS). Для анализов использован масс-спектрометр $\mathrm{Nu}$ Plasma HR MC-ICP-MS (Nu Instruments, Великобритания), совмещенный с 193-нм эксимерной системой лазерной абляции (RESOlution M-50, Resonetics LLC, США). Размер пучка составлял 55 микрон, время анализа - 45 с. Для калибровки использованы зерна цирконовых стандартов 91500 и Plešovice. Коррекция дрейфа сигнала измеряемых изотопов, учет фо- новых сигналов, расчет изотопных отношений и их погрешностей выполнены в программе ICPMSDataCal [Lin et al., 2016].

\section{Петрография}

Среди габбровых пород массива горы Улькенлаба встречены три разновидности: троктолиты, габбро и амфиболовые габбро. Троктолиты - мелко- среднезернистые породы (рис. 3, a), содержащие до 25 об. \% оливина, представленного мелкими субидиоморфными зернами, повсеместно окруженными реакционными каймами. Плагиоклаз занимает до 60 об. \%, клинопироксен составляет не более 10 об. \% и образует единичные пойкилитовые зер- 
на. Габбро слагают основной объем массива, это мелко-среднезернистые породы, сложенные плагиоклазом (50-60 об. \%) и клинопироксеном (4050 об. \%). Амфиболовые габбро (рис. 3, б) распространены в восточной части массива, это среднезернистые породы, сложенные плагиоклазом (5060 об. \%), клинопироксеном (20 об. \%) и зеленым магматическим амфиболом (20-30 об. \%). Диориты сложены преимущественно плагиоклазом и зеле- ным амфиболом, клинопироксен занимает не более 10 об. \%; в некоторые разностях диоритов встречается позднемагматический интерстициальный кварц, до 10 об. \%.

Интрузивные гранитоиды в изученных образцах представлены двумя разновидностями. Преобладающими являются амфибол-биотитовые граниты (рис. 3, в) - это мелко-среднезернистые породы с гипидиоморфнозернистой структурой.
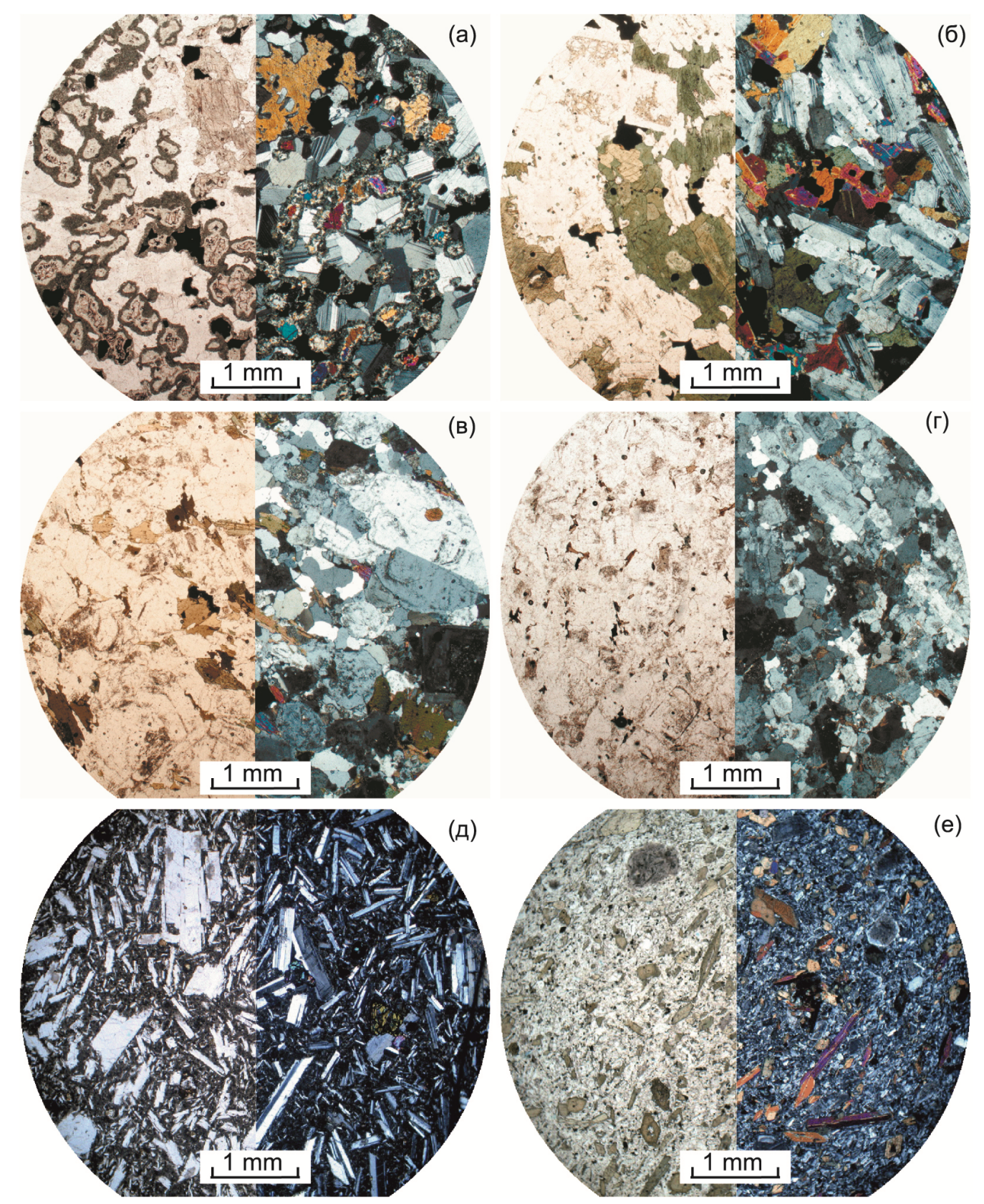

Рис. 3. Петрография исследованных разновидностей пород саурской серии

(а) - троктолит (оливиновое лейкогаббро) саурского комплекса; (б) - амфиболовое габбро саурского комплекса; (в) - амфиболбиотитовый гранит бугазского комплекса; (г) - лейкократовый биотитовый плагиогранит бугазского комплекса; (д) - долеритовый порфирит с оливином, «постгранитная» дайка; (е) - спессартит, «постгранитная» дайка

Fig. 3. Petrography of rocks of Saur series

(a) - troctolite (Ol leucogabbro) of Saur complex; (b) - Amp gabbro of Saur complex; (c) - Amp-Bt granite of Bugaz complex; (d) leucocratic Bt plagiogranite of Bugaz complex; (e) - porphyry dolerite with olivine, post-granite dike; (f) - spessartite, post-granite dike 
Зеленый амфибол в виде идиоморфных зерен занимает 5-10 об. \%, лейсты биотита - 10-15 об. \%. Среди салических минералов плагиоклаз преобладает над калишпатом, кварц (до 20 об. \%) представлен ксеноморфными зернами. Менее распространены относительно лейкократовые биотитовые плагиограниты (рис. 3, г), в них темноцветы занимают не более 10 об. \% и представлены мелкими лейстами биотита. Абсолютно преобладающим полевым шпатом является плагиоклаз, калиевый полевой шпат встречен в единичных случаях. Породы постинтрузивных базитовых даек представлены несколькими разновидностями. Наиболее примитивными являются долеритовые порфириты (рис. 3, д). Это породы с выраженной офитовой или долеритовой структурой, образованной разноразмерными (от 57 мм до 1-2 мм) лейстами плагиоклаза. Около 510 об. \% занимают мелкие идиоморфные вкрапленники оливина. Матрикс породы сложен мелкими лейстами плагиоклаза, мельчайшими зернами пироксена. Некоторые дайки сложены долеритали или микрогаббро, в которых преобладает идиоморфный плагиоклаз и ксеноморфный пироксен, в нескольких дайках встречены зерна амфибола или биотита. Cneccapmumbl, слагающие несколько даек северовосточного простирания, - порфировидные породы с идиоморфными вкрапленниками зеленого амфибола, расположенными в матриксе из мелких лейст плагиоклаза, зерен клинопироксена и амфибола (рис. 3, е). Диоритовые порфириты - светло-серые породы с преобладанием плагиоклаза, крупные лейсты которого в виде вкрапленников занимают до 20 об. \%; матрикс породы сложен лейстами плагиоклаза и зернами амфибола.

\section{Вещественный состав и источники магм}

Для характеристики вещественного состава пород саурской серии использованы 14 авторских представительных анализов (табл. 1), и данные о содержании петрогенных компонентов (175 анализов), из [Ермолов и др., 1977]. Породы саурской серии имеют широкий спектр составов - от габбро-перидотитов до гранитов, в целом соответствуют породам нормальной щелочности (рис. 4). Соотношения главных петрогенных компонентов представлены на вариационных диаграммах Харкера (рис. 5). С ростом кремнекислотности наблюдается уменьшение содержаний $\mathrm{Al}_{2} \mathrm{O}_{3}, \mathrm{CaO}, \mathrm{FeO}^{*}, \mathrm{TiO}_{2}$. Составы пород всех комплексов серии формируют общий тренд, однако граниты бугазского комплекса обогащены калием (рис. 5, ж). Для габброидов и диоритов характерны отрицательная корреляция содержаний $\mathrm{MgO} / \mathrm{CaO}$ и отсутствие корреляций $\mathrm{MgO} / \mathrm{Al}_{2} \mathrm{O}_{3}$, что может свидетельствовать о преимущественном фракционировании клинопироксена при эволюции базитовых магм. В наиболее магнезиальных по составу троктолитах оливин, содержание которого достигает 30 об. \%, вероятно, является кумулятивной фазой. Исследованные нами породы по вещественным характеристикам соответствуют отмеченным ранее химическим особенностям выделенных комплексов. Габбро соответствуют габброидам саурского комплекса, исследованные граниты - породам бугазского комплекса. Постгранитные базитовые дайки близки по составу к описанным в [Ермолов и др., 1977], они характеризуются повышенным содержанием щелочей и калия относительно других базитовых пород серии.

По содержаниям редких элементов изученные группы пород имеют отличия (рис. 6). Габбро характеризуются почти плоскими спектрами распределения РЗЭ с содержаниями на уровне 10 хондритовых (троктолиты наиболее деплетированы РЗЭ). На спайдер-диаграммах в габбро отчетливо заметны минимумы в содержаниях $\mathrm{Th}, \mathrm{Nb}, \mathrm{Zr}$; выражен максимум по Sr. Граниты бугазского комплекса демонстрируют обогащение легкими лантаноидами относительно тяжелых $\left(\mathrm{La} / \mathrm{Yb}_{\mathrm{N}}\right.$ от 7 до 12,5), в мультиэлементных спектрах отчетливы максимумы в концентрациях $\mathrm{Ba}, \mathrm{K}, \mathrm{Sr}$, слабое обогащение по $\mathrm{Zr}$ и $\mathrm{Hf}$; минимумы в содержаниях $\mathrm{Ta}$ и $\mathrm{Nb}$. Базитовые породы постгранитных даек характеризуются наиболее обогащенным составом среди изученных пород (см. рис. 6). Спектры РЗЭ имеют отрицательный наклон $\left(\mathrm{La} / \mathrm{Yb}_{\mathrm{N}}\right.$ от 8,5 до 13,5$)$, в мультиэлементных спектрах наблюдаются слабые максимумы по $\mathrm{Ba}, \mathrm{U}, \mathrm{Sr}$; минимум в концентрациях $\mathrm{Ta}$ и $\mathrm{Nb}$ выражен не так отчетливо, как в других породах серии.

Различия в редкоэлементном составе позволяют предполагать разные источники первичных магм для пород разных комплексов. Базитовые породы являются результатом кристаллизации магм, образованных при плавлении мантийных источников. Для классификации мантийных источников в последние десятилетия обозначен ряд индикаторных редких элементов и их соотношений, используемых при определении различных геодинамических обстановок. На рис. 7 составы габбро саурского комплекса и базитовых постгранитных даек нанесены на некоторые классификационные диаграммы. По концентрациям и соотношениям $\mathrm{Ti}, \mathrm{Zr}, \mathrm{Nb}, \mathrm{Th}, \mathrm{Yb}, \mathrm{Y}$ габбро саурского комплекса близки к базальтам островных дуг, формирующимся при плавлении деплетированного источника из мантийного клина. Такая природа источника подтверждается также низкой щелочностью, относительно высокими содержаниями кальция и глинозема. Постгранитные дайки обогащены относительно габбро $\mathrm{Zr}, \mathrm{Nb}$, Th (см. рис. 7), их составы занимают промежуточное положение между базальтами островных дуг и базальтами океанических островов, а по концентрациям $\mathrm{Zr}$ они близки к внутриплитным базальтам (рис. 7, б). 


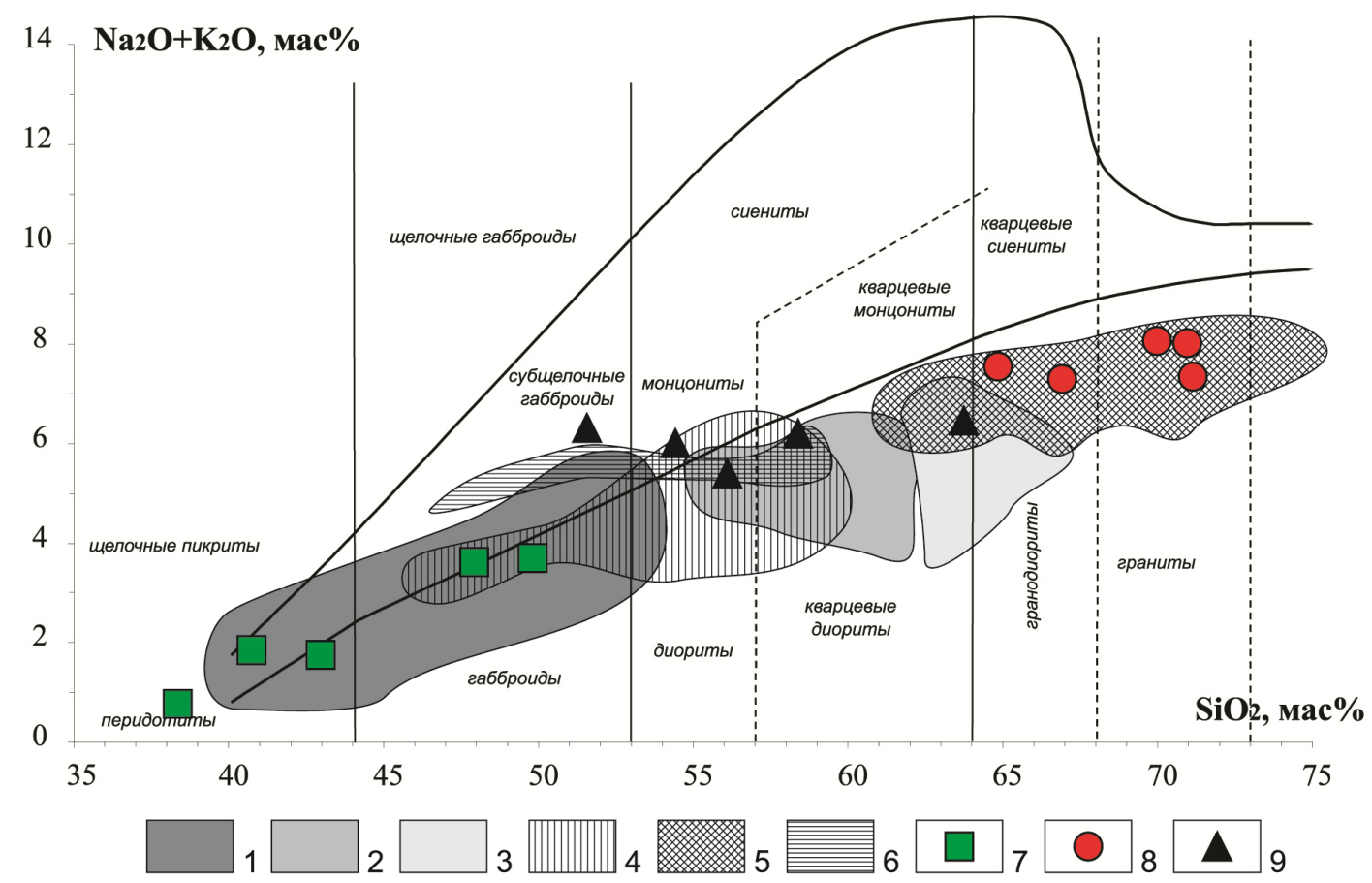

Рис. 4. Состав пород саурской серии на классификационной диаграмме « $\mathrm{SiO}_{2}-$ сумма щелочей»

1-6 - составы пород саурской серии (175 анализов, данные [Ермолов и др., 1977]): 1 - габбро саурского комплекса, 2 - диориты и кварцевые диориты саурского комплекса, 3 - тоналиты и трондьемиты саурского комплекса, 4 - базитовые дайки «межгранитного» комплекса, 5 - плагиограниты и граниты бугазского комплекса, 6 - базитовые дайки «постгранитного» комплекса; 7-9 - составы изученных нами пород: 7 - габбро массива г. Улькенлаба, 8 - граниты Бугазского массива, 9 - постгранитые базитовые дайки. Границы полей и номенклатура по [Магматические... 1983]

Fig. 4. Rock composition of Saur series on TAS-diagram

1-6 - rock compositions of Saur series (175 samples from [Ermolov et al., 1977]): 1 - gabbro of Saur complex, 2 - diorites and Qtz diorites of Saur complex, 3 - tonalities and trondemites of Saur complex, 4 - mafic dikes of "inter-granite" complex, 5 - plagiogranites and granites of Bugaz complex, 6 - mafic dikes of "post-granite" complex; 7-9 - rock compositions from this study: 7 - gabbro of Ulkenlaba massif, 8 - granites of Bugaz massif; 9 - post-granite mafic dikes. Fields and nomenclature after [Magmaticheskie... 1983]

Таблица 1

Представительные анализы пород саурской серии

Table 1

Representative compositions of rocks of Saur series

\begin{tabular}{c|c|c|c|c|c|c|c}
\hline № обр. & $\mathrm{X}-1254$ & $\mathrm{X}-1256$ & $\mathrm{X}-1259$ & $\mathrm{X}-1260$ & $\mathrm{X}-1264$ & $\mathrm{X}-1269$ & $\mathrm{X}-1266$ \\
\hline \multirow{2}{*}{ Компонент } & троктолит & $\begin{array}{c}\mathrm{Amp} \\
\text { габбро }\end{array}$ & габбро & $\begin{array}{c}\mathrm{Amp} \\
\text { габбро }\end{array}$ & $\begin{array}{c}\text { Amp-Bt } \\
\text { гранит }\end{array}$ & $\begin{array}{c}\text { Amp-Bt } \\
\text { гранит }\end{array}$ & $\begin{array}{c}\mathrm{Bt} \\
\text { лейкогранит }\end{array}$ \\
\hline $\mathrm{SiO}_{2}$ & 38,35 & 42,97 & 47,94 & 49,83 & 64,88 & 66,95 & 70,01 \\
$\mathrm{TiO}_{2}$ & 1,03 & 0,90 & 0,98 & 0,85 & 0,45 & 0,40 & 0,17 \\
$\mathrm{Al}_{2} \mathrm{O}_{3}$ & 19,26 & 21,04 & 19,07 & 19,74 & 17,25 & 15,96 & 16,26 \\
$\mathrm{FeO}$ & 17,90 & 13,91 & 12,11 & 10,87 & 3,15 & 3,82 & 1,64 \\
$\mathrm{MnO}$ & 0,17 & 0,19 & 0,20 & 0,17 & 0,06 & 0,06 & 0,02 \\
$\mathrm{MgO}$ & 9,66 & 5,71 & 5,32 & 5,02 & 1,20 & 1,74 & 0,42 \\
$\mathrm{CaO}$ & 13,31 & 13,33 & 10,28 & 10,29 & 3,65 & 2,86 & 2,00 \\
$\mathrm{Na} 2$ & 0,70 & 1,59 & 3,46 & 3,42 & 5,88 & 4,83 & 5,73 \\
$\mathrm{~K}_{2} \mathrm{O}$ & 0,06 & 0,15 & 0,16 & 0,29 & 1,67 & 2,47 & 2,33 \\
$\mathrm{P}_{2} \mathrm{O}_{5}$ & 0,02 & 0,13 & 0,20 & 0,14 & 0,17 & 0,12 & 0,07 \\
$П . п . П$. & 0,36 & 0,53 & 0,49 & 0,39 & 0,84 & 0,54 & 0,43 \\
$\mathrm{Cyмма}$ & 99,17 & 99,15 & 99,09 & 100,00 & 99,03 & 99,53 & 99,11 \\
\hline $\mathrm{Rb}$ & 0,5 & 0,8 & 0,7 & 2,1 & 13,7 & 22,6 & 14,2 \\
$\mathrm{Sr}$ & 463 & 561 & 567 & 585 & 1058 & 1001 & 1340 \\
$\mathrm{Y}$ & 4,1 & 14,1 & 18,8 & 15,7 & 11,0 & 9,7 & 3,1 \\
$\mathrm{Zr}$ & 4 & 19 & 22 & 33 & 95 & 91 & 78 \\
$\mathrm{Nb}$ & 0,2 & 1,0 & 1,9 & 1,8 & 4,6 & 2,8 & 1,5 \\
$\mathrm{Cs}$ & 0,1 & 0,1 & 0,1 & 0,1 & 0,2 & 0,4 & 0,2 \\
$\mathrm{Ba}$ & 12 & 40 & 69 & 83 & 706 & 978 & 1359 \\
$\mathrm{La}$ & 0,8 & 3,3 & 5,5 & 5,7 & 13,2 & 11,7 & 5,7 \\
$\mathrm{Ce}$ & 2,0 & 8,3 & 14,0 & 13,5 & 30,2 & 24,4 & 11,2
\end{tabular}


С.В. Хромых, П.Д. Котлер, Д.В. Семенова

\begin{tabular}{c|c|c|c|c|c|c|c}
\hline № обр. & $\mathrm{X}-1254$ & $\mathrm{X}-1256$ & $\mathrm{X}-1259$ & $\mathrm{X}-1260$ & $\mathrm{X}-1264$ & $\mathrm{X}-1269$ & $\mathrm{X}-1266$ \\
\hline Компонент & троктолит & $\begin{array}{c}\mathrm{Amp} \\
\text { габбро }\end{array}$ & габбро & $\begin{array}{c}\text { Amp } \\
\text { габбро }\end{array}$ & $\begin{array}{c}\text { Amp-Bt } \\
\text { гранит }\end{array}$ & $\begin{array}{c}\text { Amp-Bt } \\
\text { гранит }\end{array}$ & $\begin{array}{c}\mathrm{Bt} \\
\text { лейкогранит }\end{array}$ \\
\hline $\mathrm{Pr}$ & 0,3 & 1,2 & 2,1 & 1,9 & 3,9 & 2,6 & 1,2 \\
$\mathrm{Nd}$ & 1,5 & 6,7 & 10,2 & 8,9 & 15,5 & 9,5 & 4,4 \\
$\mathrm{Sm}$ & 0,45 & 2,02 & 2,96 & 2,24 & 3,07 & 2,15 & 0,80 \\
$\mathrm{Eu}$ & 0,33 & 0,71 & 1,05 & 0,90 & 0,69 & 0,57 & 0,25 \\
$\mathrm{Gd}$ & 0,82 & 2,40 & 3,51 & 2,69 & 2,58 & 1,84 & 0,81 \\
$\mathrm{~Tb}$ & 0,13 & 0,40 & 0,51 & 0,40 & 0,32 & 0,28 & 0,11 \\
$\mathrm{Dy}$ & 0,79 & 2,54 & 3,29 & 2,78 & 1,93 & 1,47 & 0,53 \\
$\mathrm{Ho}$ & 0,17 & 0,51 & 0,65 & 0,57 & 0,36 & 0,34 & 0,11 \\
$\mathrm{Er}$ & 0,42 & 1,53 & 1,85 & 1,53 & 1,13 & 0,94 & 0,33 \\
$\mathrm{Tm}$ & 0,06 & 0,23 & 0,27 & 0,23 & 0,18 & 0,14 & 0,05 \\
$\mathrm{Yb}$ & 0,40 & 1,27 & 1,62 & 1,40 & 1,25 & 0,94 & 0,35 \\
$\mathrm{Lu}$ & 0,06 & 0,20 & 0,23 & 0,20 & 0,18 & 0,14 & 0,05 \\
$\mathrm{Hf}$ & 0,23 & 0,70 & 0,88 & 1,08 & 2,70 & 2,65 & 2,14 \\
$\mathrm{Ta}$ & 0,05 & 0,08 & 0,08 & 0,08 & 0,35 & 0,21 & 0,09 \\
$\mathrm{Th}$ & 0,03 & 0,11 & 0,09 & 0,31 & 3,03 & 2,48 & 0,80 \\
$\mathrm{U}$ & 0,02 & 0,06 & 0,06 & 0,11 & 1,02 & 0,87 & 0,45 \\
$\mathrm{Sc}$ & 39 & 26 & 34 & 31 & - & - & - \\
$\mathrm{V}$ & 438 & 286 & 255 & 242 & - & - & - \\
$\mathrm{Cr}$ & 9 & 10 & 18 & 23 & - & - & - \\
$\mathrm{Co}$ & 54 & 29 & 26 & 25 & - & - & - \\
$\mathrm{Ni}$ & 38 & 10 & 14 & 12 & - & - & - \\
$\mathrm{Cu}$ & 10 & 29 & 54 & 74 & - & - & - \\
$\mathrm{Zn}$ & 82 & 93 & 79 & 81 & - & - & - \\
\hline
\end{tabular}

\begin{tabular}{|c|c|c|c|c|c|c|c|}
\hline № обр. & X-1268 & X-1263 & $\mathrm{X}-1262$ & K-17-19/2 & $\mathrm{K}-17-20 / 2$ & $\mathrm{~K}-17-22$ & X-1267 \\
\hline Компонент & $\begin{array}{c}\mathrm{Bt} \\
\text { лейкогранит }\end{array}$ & $\begin{array}{c}\mathrm{Bt} \\
\text { лейкогранит }\end{array}$ & $\begin{array}{c}\text { Вt доле- } \\
\text { рит } \\
\text { (дайка) }\end{array}$ & $\begin{array}{l}\text { Ol долерит } \\
\text { (дайка) }\end{array}$ & $\begin{array}{c}\text { Amp микро- } \\
\text { габбро } \\
\text { (дайка) }\end{array}$ & $\begin{array}{c}\text { Спессартит } \\
\text { (дайка) }\end{array}$ & $\begin{array}{c}\text { диоритовый } \\
\text { порфирит } \\
\text { (дайка) }\end{array}$ \\
\hline $\mathrm{SiO}_{2}$ & 70,99 & 71,18 & 51,59 & 54,45 & 56,12 & 58,41 & 63,78 \\
\hline $\mathrm{TiO}_{2}$ & 0,15 & 0,14 & 1,69 & 1,66 & 1,07 & 0,72 & 0,56 \\
\hline $\mathrm{Al}_{2} \mathrm{O}_{3}$ & 16,06 & 16,08 & 16,69 & 16,21 & 16,09 & 17,31 & 16,57 \\
\hline $\mathrm{FeO}^{*}$ & 1,28 & 1,52 & 11,22 & 10,61 & 9,40 & 6,79 & 4,93 \\
\hline $\mathrm{MnO}$ & 0,02 & 0,02 & 0,12 & 0,15 & 0,11 & 0,09 & 0,08 \\
\hline $\mathrm{MgO}$ & 0,37 & 0,50 & 3,71 & 3,92 & 4,19 & 3,71 & 2,61 \\
\hline $\mathrm{CaO}$ & 1,81 & 2,34 & 5,46 & 6,41 & 6,53 & 5,66 & 4,05 \\
\hline $\mathrm{Na}_{2} \mathrm{O}$ & 6,15 & 5,97 & 4,30 & 4,02 & 3,76 & 4,65 & 4,54 \\
\hline $\mathrm{K}_{2} \mathrm{O}$ & 1,87 & 1,37 & 2,02 & 2,00 & 1,65 & 1,56 & 1,92 \\
\hline $\mathrm{P}_{2} \mathrm{O}_{5}$ & 0,05 & 0,05 & 0,35 & 0,55 & 0,17 & 0,24 & 0,18 \\
\hline П.п.п. & 0,33 & 0,59 & 3,19 & 0,59 & 1,15 & 0,86 & 0,99 \\
\hline Сумма & 99,17 & 99,78 & 99,54 & 99,66 & 99,43 & 99,46 & 99,86 \\
\hline $\mathrm{Rb}$ & 11,0 & 10,4 & 32,2 & 26,0 & 42,7 & 26,2 & 33,0 \\
\hline $\mathrm{Sr}$ & 1203 & 1253 & 747 & 585 & 577 & 670 & 867 \\
\hline $\mathrm{Y}$ & 4,0 & 3,7 & 18,5 & 39,2 & 12,0 & 13,4 & 11,5 \\
\hline $\mathrm{Zr}$ & 76 & 74 & 166 & 333 & 75 & 144 & 122 \\
\hline $\mathrm{Nb}$ & 1,8 & 1,3 & 12,7 & 15,0 & 6,4 & 4,8 & 4,9 \\
\hline $\mathrm{Cs}$ & 0,1 & 0,1 & 0,7 & 0,7 & 1,2 & 0,4 & 0,5 \\
\hline $\mathrm{Ba}$ & 1580 & 1181 & 514 & 651 & 480 & 510 & 807 \\
\hline $\mathrm{La}$ & 6,1 & 4,0 & 22,7 & 38,2 & 12,6 & 19,9 & 18,1 \\
\hline $\mathrm{Ce}$ & 11,5 & 8,0 & 47,0 & 77,9 & 25,9 & 40,4 & 36,7 \\
\hline $\mathrm{Pr}$ & 1,4 & 1,0 & 6,0 & 10,1 & 3,2 & 5,2 & 4,3 \\
\hline $\mathrm{Nd}$ & 4,6 & 3,7 & 24,2 & 41,4 & 13,2 & 21,5 & 17,1 \\
\hline $\mathrm{Sm}$ & 0,95 & 0,78 & 4,85 & 8,36 & 2,95 & 4,58 & 3,07 \\
\hline $\mathrm{Eu}$ & 0,24 & 0,27 & 1,45 & 2,20 & 0,89 & 1,24 & 0,76 \\
\hline $\mathrm{Gd}$ & 0,91 & 0,76 & 5,08 & 8,01 & 3,00 & 3,63 & 2,73 \\
\hline $\mathrm{Tb}$ & 0,13 & 0,11 & 0,67 & 1,25 & 0,45 & 0,51 & 0,38 \\
\hline Dy & 0,59 & 0,54 & 3,81 & 7,10 & 2,45 & 2,51 & 1,92 \\
\hline Ho & 0,11 & 0,11 & 0,65 & 1,41 & 0,45 & 0,48 & 0,40 \\
\hline $\mathrm{Er}$ & 0,37 & 0,34 & 1,81 & 3,85 & 1,23 & 1,22 & 1,13 \\
\hline $\mathrm{Tm}$ & 0,06 & 0,06 & 0,26 & 0,54 & 0,16 & 0,18 & 0,17 \\
\hline $\mathrm{Yb}$ & 0,35 & 0,41 & 1,50 & 3,25 & 0,96 & 1,04 & 1,12 \\
\hline $\mathrm{Lu}$ & 0,06 & 0,06 & 0,21 & 0,51 & 0,15 & 0,15 & 0,16 \\
\hline Hf & 2,21 & 2,23 & 3,80 & 7,10 & 2,02 & 3,53 & 3,30 \\
\hline $\mathrm{Ta}$ & 0,12 & 0,11 & 0,83 & 0,86 & 0,36 & 0,36 & 0,38 \\
\hline $\mathrm{Th}$ & 0,71 & 0,62 & 3,93 & 3,52 & 2,63 & 3,31 & 3,56 \\
\hline $\mathrm{U}$ & 0,18 & 0,48 & 1,27 & 1,01 & 1,02 & 1,76 & 1,19 \\
\hline
\end{tabular}




\begin{tabular}{|c|c|c|c|c|c|c|c|}
\hline № обр. & X-1268 & X-1263 & $\mathrm{X}-1262$ & K-17-19/2 & $\mathrm{K}-17-20 / 2$ & $\mathrm{~K}-17-22$ & $\mathrm{X}-1267$ \\
\hline Компонент & $\begin{array}{c}\mathrm{Bt} \\
\text { лейкогранит }\end{array}$ & $\begin{array}{c}\mathrm{Bt} \\
\text { лейкогранит }\end{array}$ & $\begin{array}{c}\text { Вt доле- } \\
\text { рит } \\
\text { (дайка) }\end{array}$ & $\begin{array}{l}\text { Ol долерит } \\
\text { (дайка) }\end{array}$ & $\begin{array}{c}\text { Amp микро- } \\
\text { габбро } \\
\text { (дайка) }\end{array}$ & $\begin{array}{l}\text { Спессартит } \\
\text { (дайка) }\end{array}$ & $\begin{array}{c}\text { диоритовый } \\
\text { порфирит } \\
\text { (дайка) }\end{array}$ \\
\hline $\mathrm{Sc}$ & - & - & 14 & - & - & - & 11 \\
\hline $\mathrm{V}$ & - & - & 141 & - & - & - & 74 \\
\hline $\mathrm{Cr}$ & - & - & 22 & - & - & - & 61 \\
\hline $\mathrm{Co}$ & - & - & 30 & - & - & - & 12 \\
\hline $\mathrm{Ni}$ & - & - & 35 & - & - & - & 31 \\
\hline $\mathrm{Cu}$ & - & - & 43 & - & - & - & 23 \\
\hline $\mathrm{Zn}$ & - & - & 102 & - & - & - & 57 \\
\hline
\end{tabular}

Примечание: прочерк - содержание элемента не определялось.

Note: dash - the content of the element was not determined.
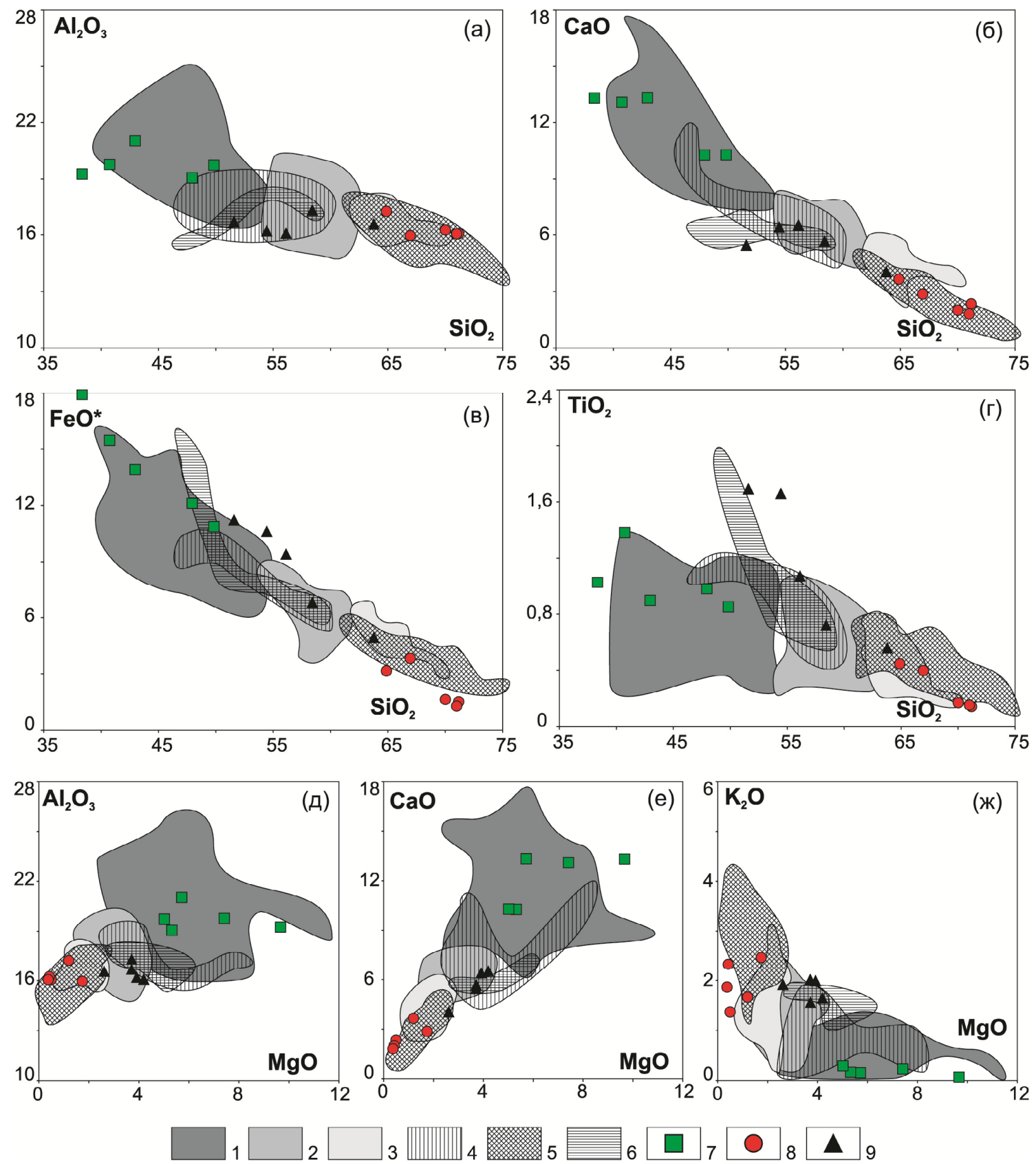

Рис. 5. Составы пород саурской серии на двухкомпонентных диаграммах

$\mathrm{SiO}_{2}-\mathrm{Al}_{2} \mathrm{O}_{3}$ (а), $\mathrm{SiO}_{2}-\mathrm{CaO}$ (б), $\mathrm{SiO}_{2}-\mathrm{FeO}^{*}$ (в), $\mathrm{SiO}_{2}-\mathrm{TiO}_{2}$ (г), $\mathrm{MgO}-\mathrm{Al}_{2} \mathrm{O}_{3}$ (д), $\mathrm{MgO}-\mathrm{CaO}$ (е), $\mathrm{MgO}-\mathrm{K}_{2} \mathrm{O}$ (ж). Условные обозначения см. на рис. 4

Fig. 5. Rock compositions of two-component diagrams

$\mathrm{SiO}_{2}-\mathrm{Al}_{2} \mathrm{O}_{3}$ (a), $\mathrm{SiO}_{2}-\mathrm{CaO}$ (b), $\mathrm{SiO}_{2}-\mathrm{FeO}^{*}$ (c), $\mathrm{SiO}_{2}-\mathrm{TiO}_{2}$ (d), $\mathrm{MgO}-\mathrm{Al}_{2} \mathrm{O}_{3}$ (e), $\mathrm{MgO}-\mathrm{CaO}$ (f), $\mathrm{MgO}-\mathrm{K}_{2} \mathrm{O}$ (g). Legend see on fig. 4 

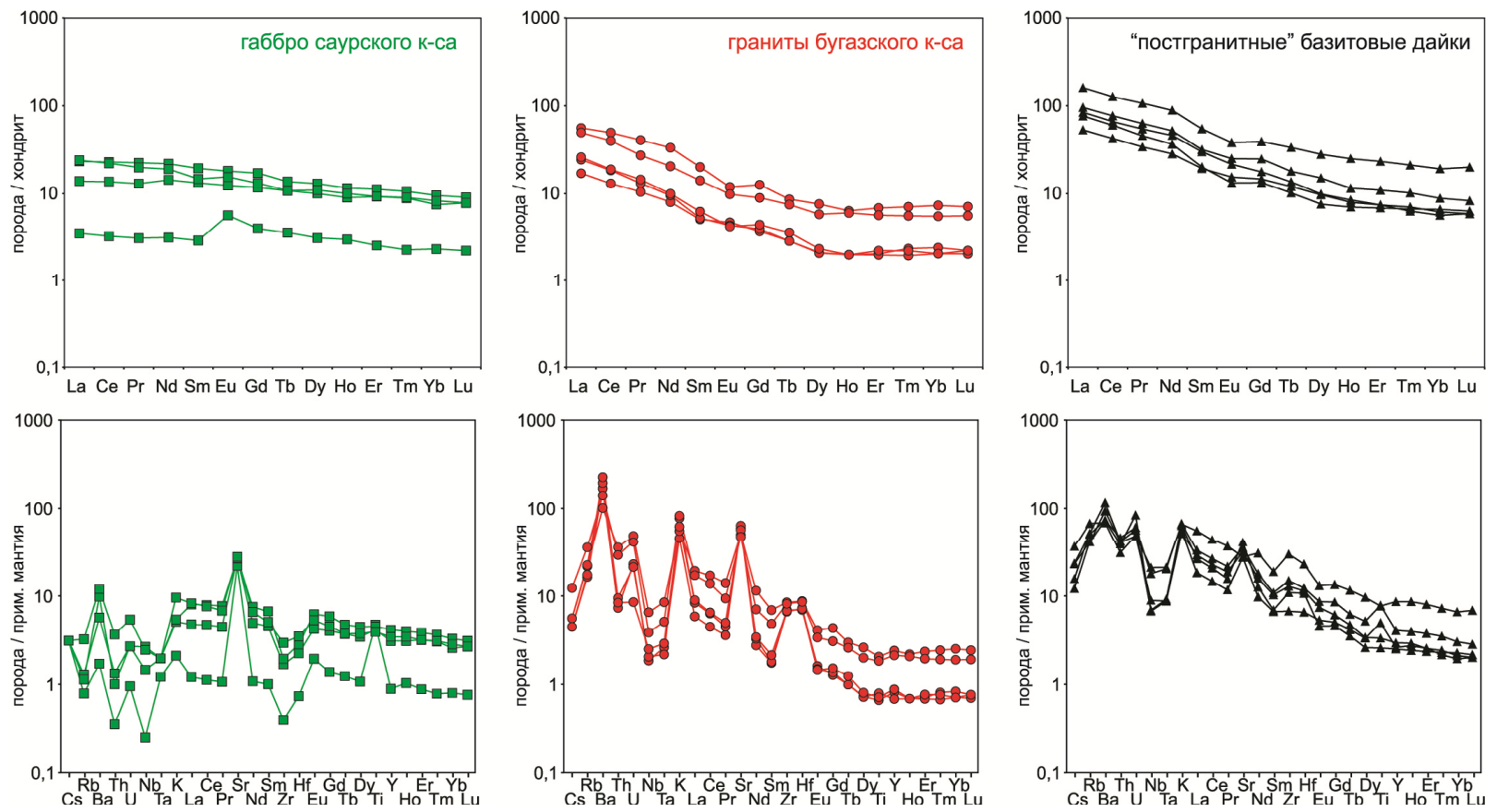

Рис. 6. Спектры распределения редкоземельных элементов (вверху) и спайдер-диаграммы (внизу) для составов пород саурской серии

Содержания элементов нормированы на состав хондрита и примитивной мантии [Sun, McDonough, 1989]

Fig. 6. REE-spectra (top) and spider diagrams (bottom) for rock compositions of Saur series Concentrations are normalized on chondrite and primitive mantle [Sun, McDonough, 1989]
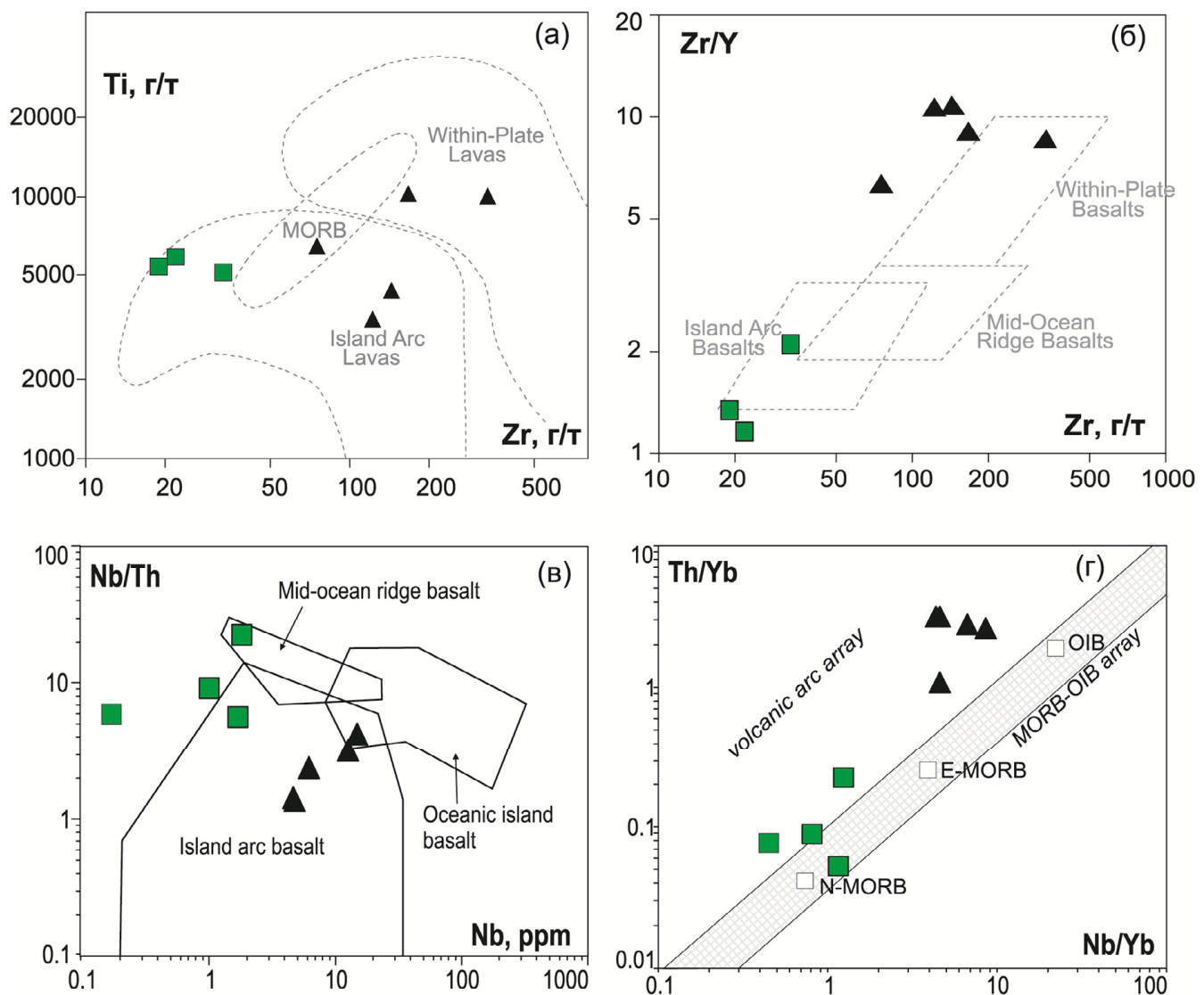

Рис. 7. Состав габбро саурского комплекса и постгранитных базитовых даек на классификационных геодинамических диаграммах

a) $\mathrm{Zr}$ - Ti [Pearce, 1982]; б) $\mathrm{Zr}-\mathrm{Zr} / \mathrm{Y}$ [Pearce, Norry, 1979]; в) $\mathrm{Nb}-\mathrm{Nb} / \mathrm{Th}$ [Yang et al., 2014]; г) Nb/Yb - Th/Yb [Pearce, 2008]

Fig. 7. Composition of Saur gabbro andpost0granite mafic dikes on geodynamic classification diagrams a) $\mathrm{Zr}-\mathrm{Ti}$ [Pearce, 1982]; b) Zr - Zr/Y [Pearce, Norry, 1979]; c) Nb - Nb/Th [Yang et al., 2014]; d) Nb/Yb - Th/Yb [Pearce, 2008] 


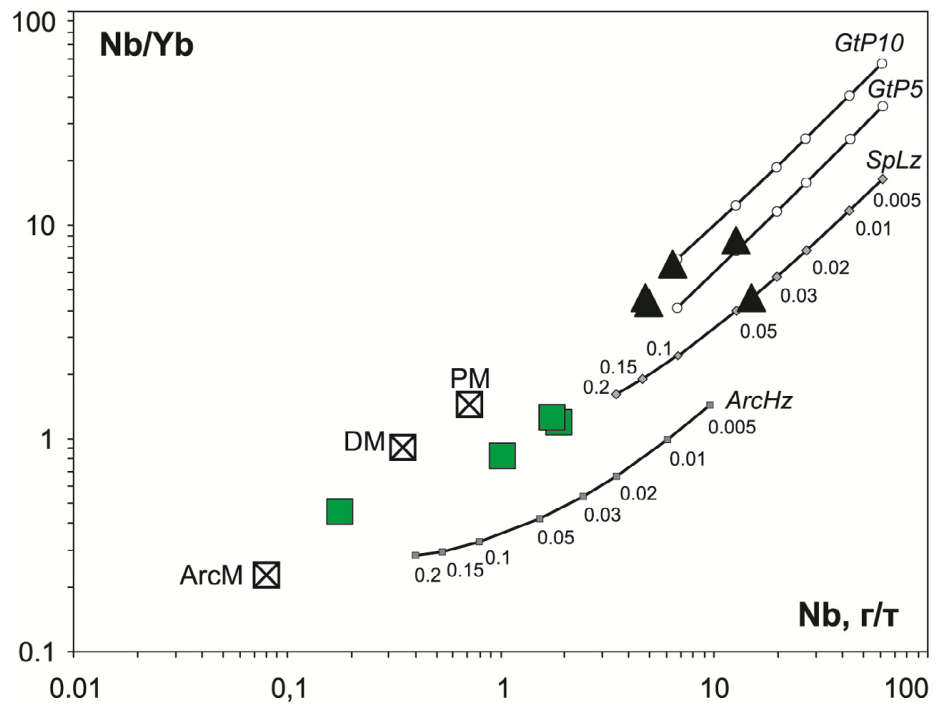

Рис. 8. Диаграмма $\mathrm{Nb}-\mathrm{Nb} / \mathrm{Yb}$

Сопоставление составов габбро саурского комплекса и постгранитных базитовых даек с результатами геохимического моделирования в $\mathrm{Nb}-\mathrm{Yb}$ системе по [Yang et al., 2014; Safonova et al., 2018]. Кривые обозначают тренд составов, образующихся при плавлении гранатового перидотита с содержанием 5\% и 10\% граната (GtP 5, GtP 10), шпинелевого лерцолита (SpLz) и сильно деплетированного реститового подостроводужного гарцбургита ( $\mathrm{ArcHz})$. Цифры обозначают степень плавления. Составы источников, использованные для моделирования: PM - примитивная мантия, DM - деплетированная мантия, АrcM - подостроводужная мантия

\section{Fig. 8. $\mathrm{Nb}-\mathrm{Nb} / \mathrm{Yb}$ diagram}

Data for the Saur gabbro and post-granite mafic dikes are compared with results of modeling in the Nb-Yb system [Yang et al., 2014; Safonova et al., 2018]. The calculated melting curves are for garnet peridotite containing 5\% and 10\% of garnet (GtP5, GtP10), spinel lherzolite $(\mathrm{SpLz})$, and highly depleted sub-arc harzburgite $(\mathrm{ArcHz})$. Numbers are melt fractions. $\mathrm{PM}=$ primitive mantle, $\mathrm{DM}=$ depleted mantle, $\mathrm{ArcM}=$ arc mantle
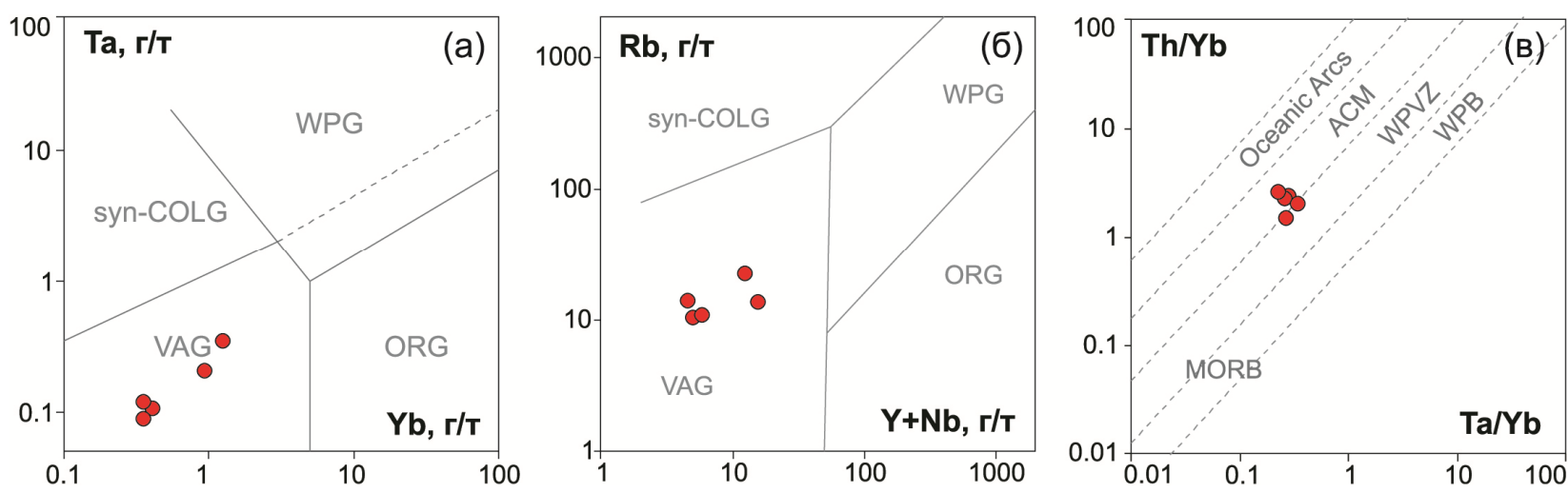

Рис. 9. Состав гранитов бугазского комплекса на классификационных геодинамических диаграммах a) $\mathrm{Yb}$ - Ta [Pearce et al., 1984]; б) $\mathrm{Yb}+\mathrm{Nb}-\mathrm{Rb}$ [Pearce et al., 1984]; в) $\mathrm{Ta} / \mathrm{Yb}-\mathrm{Th} / \mathrm{Yb}$ [Schandl, Gorton, 2002]. Поля составов пород: ORG (Ocean Ridge Granites) - граниты океанических хребтов, VAG (Volcanic Arc Granites) - граниты вулканических дуг, WPG (Within Plate Granites) - внутриплитные граниты, syn-COLG (Collision Granites) - синколлизионные граниты, Ocеanic Arcs - океанические дуги, ACM (Active Continental Margins) - активные континентальные окраины, WPVZ (Within-Plate Volcanic Zones) - внутриплитные вулканические зоны, WPB (Within-Plate Basalts) - внутриплитные базальты, MORB (Mid-Oceanic Ridge Basalts) - базальты срединно-океанических хребтов

Fig. 9. Composition of Bugaz granites on geodynamic classification diagrams

a) $\mathrm{Yb}-\mathrm{Ta}$ [Pearce et al., 1984]; b) $\mathrm{Yb}+\mathrm{Nb}-\mathrm{Rb}$ [Pearce et al., 1984]; c) $\mathrm{Ta} / \mathrm{Yb}-\mathrm{Th} / \mathrm{Yb}$ [Schandl, Gorton, 2002]. Fields: ORG Ocean Ridge Granites, VAG - Volcanic Arc Granites, WPG - Within Plate Granites, syn-COLG - Collision Granites; ACM - Active Continental Margins, WPVZ - Within-Plate Volcanic Zones, WPB - Within-Plate Basalts, MORB - Mid-Oceanic Ridge Basalts

Обогащенный состав постгранитных даек также выражается в повышенных содержаниях калия, фосфора и целого ряда редких элементов. Очевидно, что базитовые магмы, сформировавшие дайки, про- изошли из другого (более обогащенного) мантийного источника.

Для определения характера мантийного источника мы использовали результаты геохимического модели- 
рования в $\mathrm{Nb}-\mathrm{Yb}$ системе [Yang et al., 2014; Safonova et al., 2018]. Составы изученных пород саурской серии были сопоставлены с результатами численного моделирования плавления различных мантийных источников (рис. 8). Сопоставление показывает, что магмы габбро саурского комплекса могли быть образованы при частичном плавлении шпинелевого лерцолита деплетированной мантии. Составы постгранитных базитовых даек обогащены ниобием, сформировавшие их магмы могли появиться в результате плавления менее деплетрованного мантийного источника (гранатовых перидотитов).

Составы изученных гранитов бугазского комплекса на классификационных геодинамических диаграммах по содержаниям $\mathrm{Yb}, \mathrm{Ta}, \mathrm{Rb}, \mathrm{Y}, \mathrm{Nb}$ попадают в поля гранитов вулканических дуг (рис. 9, $a$, б). По концентрациям Ta, Th и $\mathrm{Yb}$ их составы отвечают активным континентальным окраинам (рис. 9, в). В целом по вещественным характеристикам и минеральному составу гранитоиды бугазского комплекса отвечают гранитоидам I типа, что подразумевает преобладание вулканогенно-осадочного субстрата в источнике гранитоидных магм.

\section{Геохронологические и изотопные данные}

По геологическим данным и результатам K-Ar датирования возраст саурской серии был определен как конец раннего карбона (340-318 млн лет) [Ермолов и др., 1977]. Мы провели геохронологические исследования пород саурской серии с помощью U$\mathrm{Pb}$ изотопных методов, по единичным зернам цирконов. Для датирования были выбраны (см. местоположение на рис. 2): 1) кварцсодержащий диорит саурского комплекса (проба К-17-25), 2) амфиболбиотитовый гранит бугазского комплекса (проба К-17-19/1), 3) лейкократовый биотитовый плагиогранит бугазского комплекса (проба X-1268), 4) спессартит одной из наиболее поздних даек северовосточного простирания (проба К-17-22). Пробы весом около 7 кг были издроблены и просеяны, из них с помощью магнитной сепарации и применения тяжелых жидкостей были выделены монофракции цирконов. Для дальнейших прецизионных исследований были выбраны идиоморфные зерна, не содержащие трещин или крупных включений. Для исследования внутреннего строения выбранных зерен были использованы катодолюминесцентные изображения, полученные с помощью растрового электронного микроскопа JSM 6510 LV (ЦКП МИИ ИГМ СО РАН). Большинство цирконов представлены слабоудлиненными зернами, габитусные формы - призма и бипирамиды. Внутреннее строение цирконов характеризуется в целом концентрической зональностью, для некоторых зерен из кварцевого диорита также наблюдается секториальная зональность. Морфология и внутреннее строение изученных цирконов не вызывают сомнений в их магматическом происхождении.
Необходимо отметить, что в монофракции цирконов из спессартита поздней дайки (К-17-22) было обнаружено две группы цирконов различающейся морфологии. Цирконы одной из групп морфологически похожи на цирконы из вмещающих гранитов, и, как показали изотопные исследования, имеют одинаковый с ними возраст. Цирконы из другой группы, магматической природы, характеризуются меньшими размерами и имеют другой изотопный возраст. Именно эта группа принята нами за магматические цирконы, кристаллизовавшиеся непосредственно в дайке.

Датирование проводилось как по центральным, так и по периферическим частям зерен цирконов. Интерпретация измеренных U-Pb изотопных отношений позволила установить следующие значения возраста. Для кварцевого диорита саурского комплекса по 33 экспериментальным точкам установлено значение возраста в $330 \pm 2$ млн лет (рис. 10,a). Для амфибол-биотитового гранита бугазского комплекса по 27 экспериментальным точкам установлено значение возраста в $327 \pm 3$ млн лет (рис. 10, б). Для лейкократового биотитового плагиогранита бугазского комплекса по 13 экспериментальным точкам установлено значение возраста в $326 \pm 3$ млн лет (рис. 10,6 ). Для спессартита из поздней дайки по 9 экспериментальным точкам установлено значение возраста в $315 \pm 4$ млн лет (рис. 10, г). Таким образом возраст формирования изученных пород может быть оценен как конец раннего - начало среднего карбона в интервале 332-311 млн лет. Это в целом подтверждает предшествующие оценки возраста серии, выполненные геологическими и K-Ar геохронологическими методами [Ермолов и др., 1977].

Для установления природы мантийного источника были выполнены Sm-Nd изотопные исследования по валовым пробам пород. Были выбраны троктолит массива горы Улькенлаба (саурский комплекс), лейкократовый биотитовый плагиогранит (бугазский комплекс) и долерит из дайки северо-восточного простирания в массиве Жаксы-Койтас, в 50 км к западу от района основных исследований. Результаты измерения изотопных отношений приведены в табл. 2. Рассчитанные на возраст пород значения $\varepsilon \mathrm{Nd}_{(\mathrm{T})}$ оказались положительными, это подтверждает ювенильную природу как габбро, так и гранитов. Постгранитные дайки обогащены как $\mathrm{Sm}$, так и $\mathrm{Nd}$ и имеют отличающиеся изотопные отношения. Кроме того, нам удалось выполнить исследования Lu-Hf изотопной системы в цирконах из кварцевых диоритов саурского комплекса и амфибол-биотитовых гранитов бугазского комплекса (табл. 3). Для большинства экспериментальных точек характерны положительные значения $\varepsilon \mathrm{Hf}_{(\mathrm{T})}$, что также указывает на ювенильную природу цирконов и их происхождение из вещества деплетированной мантии. 

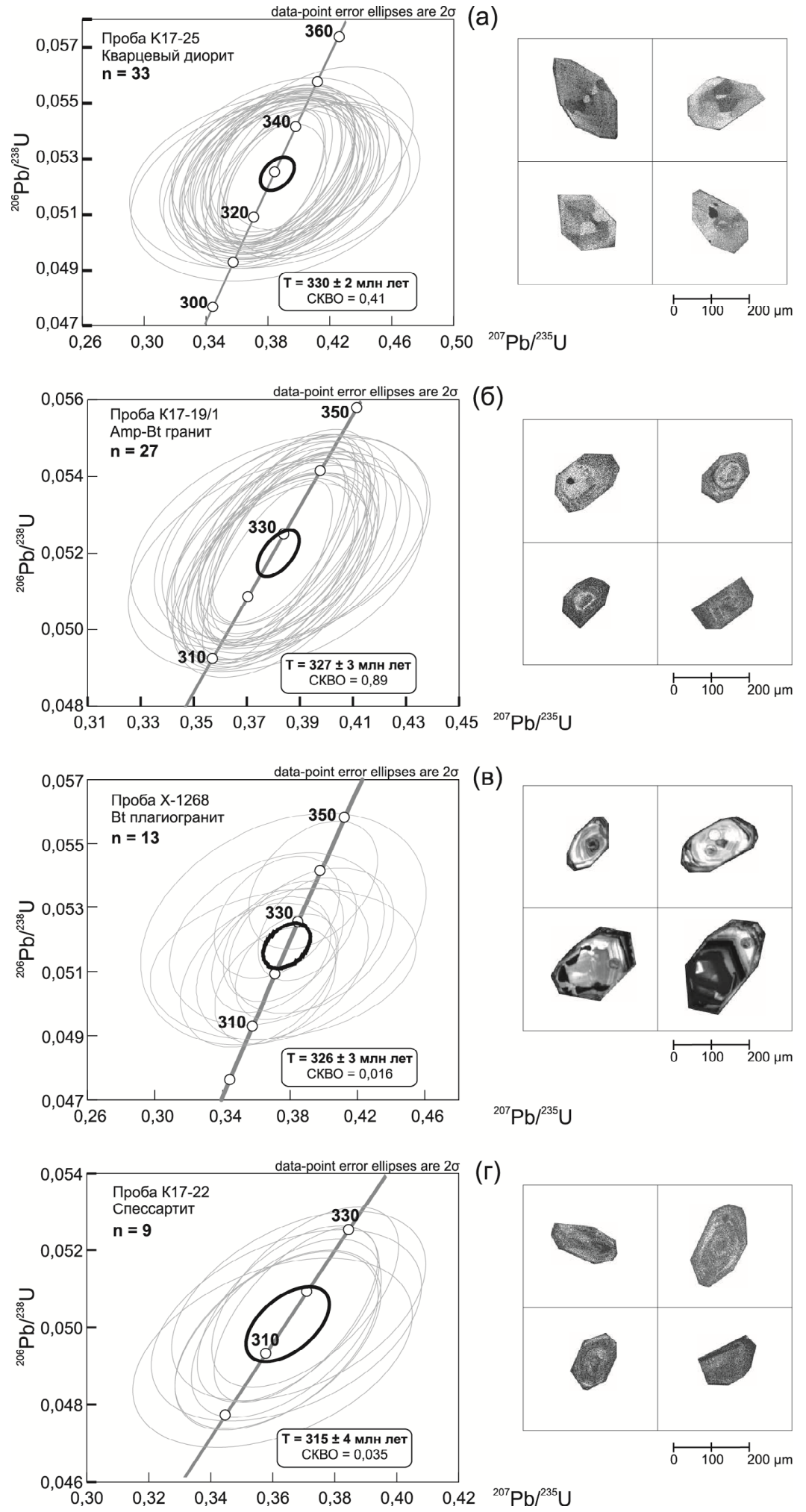

Рис. 10. Результаты U-Pb изотопного датирования цирконов из пород саурской серии

Диаграммы с конкордией: (а) - для кварцевого диорита саурского комплекса, проба К17-25, 33 экспериментальные точки; (б) для Amp-Bt гранита бугазского комплекса, проба К17-19/1, 27 экспериментальных точек; (в) - для Вt плагиогранита бугазского комплекса, проба X-1268, 13 экспериментальных точек; (г) - для спессартита из «постгранитной» дайки, проба К17-22, 9 экспериментальных точек. Справа приведены катодолюминесцентные изображения некоторых зерен цирконов. Изображения получены с помощью растрового электронного микроскопа JSM 6510 LV (ЦКП МИИ ИГМ СО РАН)

\section{Fig. 10. U-Pb dating results for zircons from the rocks of Saur series}

Concordia diagrams for: (a) - Qtz diorite of Saur complex, sample K17-25 (33 points); (b) - Amp-Bt granite of Bugaz complex, sample K17-19/1 (27 points); (c) - Bt plagiogranite of Bugaz complex, sample X-1268 (13 points); (d) - spessartite from post-granite dike, sample K17-22 (9 points). CL images of some zircon grains on the right were obtained on a JSM 6510 LV scanning electron microscope (Analytical Center, IGM, Novosibirsk) 
Таблица 2

Результаты исследования изотопного состава Nd в породах саурской серии и постгранитных дайках

Table 2

Nd isotope composition in rock of Saur series and in post-granite dikes

\begin{tabular}{c|c|c|c|c|c|c|c}
\hline Проба & Порода & $\begin{array}{c}\text { Возраст, } \\
\text { млн лет }\end{array}$ & $\mathrm{Sm}, \Gamma / \mathrm{T}$ & $\mathrm{Nd}, \Gamma / \mathrm{T}$ & ${ }^{147} \mathrm{Sm} /{ }^{144} \mathrm{Nd}$ & ${ }^{143} \mathrm{Nd} /{ }^{144} \mathrm{Nd}$ & $\varepsilon \mathrm{Nd}_{(\mathrm{T})}$ \\
\hline $\mathrm{X}-1254$ & $\begin{array}{c}\text { Троктолит, массив } \\
\text { г. Улькенлаба }\end{array}$ & 330 & 0,005 & 1,834 & 0,001528 & $0,512955 \pm 11$ & $+14,42$ \\
\hline $\mathrm{X}-1268$ & $\begin{array}{c}\text { Вт плагиогранит, } \\
\text { Бугазский массив }\end{array}$ & 326 & 0,043 & 4,566 & 0,005756 & $0,512778 \pm 11$ & $+10,69$ \\
\hline К15-29/3 & $\begin{array}{c}\text { Долерит, дайка С-В } \\
\text { простирания в Жаксы- } \\
\text { Койтасском массиве }\end{array}$ & 315 & 5,196 & 23,315 & 0,134963 & $0,512795 \pm 13$ & $+5,56$ \\
\hline
\end{tabular}

Т а бл и ц а 3

Lu-Hf изотопные данные для цирконов из кварцевых диоритов и амфибол-биотитовых гранитов саурской серии

Table 3

Lu-Hf isotope composition in zicrons from Qtz diorites and Amp-Bt granites of Saur series

\begin{tabular}{|c|c|c|c|c|c|c|c|}
\hline \multirow[t]{2}{*}{ № п.п. } & № обр. & ${ }^{176} \mathrm{Hf} /{ }^{177} \mathrm{Hf}$ & $1 \sigma$ & ${ }^{176} \mathrm{Lu} /{ }^{177} \mathrm{Hf}$ & ${ }^{176} \mathrm{Yb} /{ }^{177} \mathrm{Hf}$ & $\begin{array}{c}\text { Возраст, } \\
\text { млн лет }\end{array}$ & $\varepsilon \mathrm{Hf}(\mathrm{t})$ \\
\hline & \multicolumn{7}{|c|}{ Кварцевый диорит саурского комплекса, обр. К17-25 } \\
\hline 1 & K17-25-5 & 0,282687 & 0,000011 & 0,001654 & 0,035310 & 330,0 & 3,52 \\
\hline 2 & $\mathrm{~K} 17-25-6$ & 0,282522 & 0,000015 & 0,002294 & 0,051244 & 330,0 & $-2,48$ \\
\hline 3 & $\mathrm{~K} 17-25-7$ & 0,282646 & 0,000010 & 0,001596 & 0,036150 & 330,0 & 2,07 \\
\hline 4 & K17-25-9 & 0,282728 & 0,000013 & 0,001469 & 0,032218 & 330,0 & 5,00 \\
\hline 5 & $\mathrm{~K} 17-25-10$ & 0,282733 & 0,000013 & 0,001444 & 0,030771 & 330,0 & 5,18 \\
\hline 6 & K17-25-11 & 0,282709 & 0,000015 & 0,001659 & 0,034429 & 330,0 & 4,28 \\
\hline 7 & K17-25-13 & 0,282812 & 0,000015 & 0,001093 & 0,022289 & 330,0 & 8,08 \\
\hline 8 & K17-25-14 & 0,282459 & 0,000019 & 0,002184 & 0,051994 & 330,0 & $-4,65$ \\
\hline \multirow[t]{2}{*}{9} & K17-25-15 & 0,282678 & 0,000010 & 0,001660 & 0,035943 & 330,0 & 3,21 \\
\hline & Среднее & - & - & - & - & - & $+2,69$ \\
\hline \multicolumn{8}{|c|}{ Amp-Bt гранит бугазского комплекса, обр. К17-19/1 } \\
\hline 10 & K17-19/1-1 & 0,282869 & 0,000021 & 0,000534 & 0,012752 & 327,0 & 10,13 \\
\hline 11 & $\mathrm{~K} 17-19 / 1-4$ & 0,282860 & 0,000013 & 0,000449 & 0,010019 & 327,0 & 9,82 \\
\hline 12 & K17-19/1-5 & 0,282812 & 0,000017 & 0,000737 & 0,015975 & 327,0 & 8,08 \\
\hline 13 & $\mathrm{~K} 17-19 / 1-8$ & 0,282871 & 0,000018 & 0,000459 & 0,010706 & 327,0 & 10,24 \\
\hline 14 & $\mathrm{~K} 17-19 / 1-9$ & 0,282919 & 0,000014 & 0,000423 & 0,009803 & 327,0 & 11,94 \\
\hline 15 & K17-19/1-12 & 0,282947 & 0,000012 & 0,000458 & 0,010867 & 327,0 & 12,90 \\
\hline 16 & K17-19/1-13 & 0,282900 & 0,000010 & 0,000510 & 0,012061 & 327,0 & 11,24 \\
\hline \multirow[t]{2}{*}{17} & K17-19/1-15 & 0,282924 & 0,000011 & 0,000609 & 0,013355 & 327,0 & 12,07 \\
\hline & Среднее & - & - & - & - & - & $+10,80$ \\
\hline
\end{tabular}

\section{Анализ результатов и геодинамические обстановки формирования}

Полученные геохимические и изотопные данные свидетельствуют, что источник габбро и диоритов саурской серии имеет ювенильную природу и, вероятнее всего, представляет собой вещество деплетированной мантии. Сопоставление с результатами геохимического моделирования в $\mathrm{Nb}-\mathrm{Yb}$ системе (см. рис. 8) позволяет предполагать, что родоначальные базитовые магмы были образованы при частичном плавлении шпинелевых лерцолитов деплетированной мантии. Относительно высокие содержания кальция и глинозема при относительно невысоком содержании магния (см. рис. 5), спектры распределения редких и редкоземельных элементов (см. рис. 6,7$)$ подчеркивают соответствие изученных габброидов базитам субдукционной природы. Таким образом, подтверждаются высказанные ранее предположения, что мафические породы серии произошли при плавлении обводненной мантии в субдукционной обстановке. Учитывая единый тренд в поведении петрогенных элементов для габбро, диоритов и гранитоидов саурского комплекса (1-3 на рис. 4,5$)$, можно предполагать, что эти разности пород образовались при дифференциации первичных базитовых магм. Основной объем саурского комплекса представлен диоритами, что свидетельствует о значительной обводненности базитовых магм.

Гранитоиды бугазского комплекса, учитывая их достаточно большой объем, не могли быть сформированы при дифференциации базитовых или диоритовых магм. Наиболее вероятно формирование гранитоидных магм при частичном плавлении коровых субстратов. Геохимические признаки бугазских гранитов (рис. 6,9$)$ сближают их с гранитами вулкани- 
ческих дуг и активных континентальных окраин. Следовательно, гранитные магмы были образованы при частичном плавлении вулканических и вулканогенно-осадочных формаций в Жарма-Саурской зоне, формирование которых происходило в девоне - раннем карбоне. Это подтверждают и изотопные данные - граниты бугазского комплекса характеризуются высокими положительными значениями $\varepsilon \mathrm{Nd}_{(\mathrm{T})}$ и $\varepsilon \mathrm{Hf}_{(\mathrm{T})}$, обусловленными ювенильной природой гранитообразующих субстратов. Близкий возраст диоритов саурского комплекса и гранитов бугазского комплекса подтверждает ранее сделанные выводы, что плавление вулканогенно-осадочных субстратов происходило под воздействием базитовых глубинных очагов.

По полученным нами U-Pb датировкам, общая продолжительность формирования габбро-диоритгранитной ассоциации саурского комплекса и гранитоидной ассоциации бугазского комплекса составляет 5-8 млн лет (332-324 млн лет). Сходная природа источников и одна геодинамическая обстановка формирования подтверждают их объединение в единую саурскую габбро-гранитную серию.

Иные вещественные и возрастные характеристики демонстрируют исследованные нами постгранитные мафические дайки. Они обогащены в содержаниях калия, фосфора, легких лантаноидов, Zr и $\mathrm{Hf}$ относительно гранитоидов, диоритов и габброидов саурской серии. $\mathrm{Sm}-\mathrm{Nd}$ изотопные данные также свидетельствуют об относительно обогащенном характере мантийного источника. Существенный отрыв во времени (около 10 млн лет) от габбро и гранитов не позволяет рассматривать их в составе саурской габбро-гранитной серии.

На основании полученных нами уточнений можно внести следующие корректировки в принятую ранее схему магматизма:

I. Саурская серия, включающая 1) саурский габбро-диорит-плагиогранитовый комплекс с возрастом $330 \pm 2$ млн лет; 2) комплекс «межгранитовых» даек диоритовых порфиритов, микродиоритов, плагиогранит-порфиров с возрастом между 330 и 327 млн лет (эти дайки имеют малое распространение, их точная позиция нами не определена); 3) бугазский тоналит-гранитовый комплекс с возрастом 326-327 \pm 3 млн лет.

II. Комплекс поздних даек северо-восточного простирания с возрастом $315 \pm 4$ млн лет, характеризующийся более обогащенным составом мантийного источника.

Необходимо отметить, что по геологическим данным, дайки северо-восточного простирания в Жарма-Саурской зоне выделялись ранее в самостоятельный комплекс, названный бугазским [Щерба и др., 1976, 1998]. Бугазский дайковый комплекс коррелировали с миролюбовским комплексом даек се- веро-восточного простирания в Калба-Нарымской зоне [Лопатников и др., 1982; Щерба и др., 1998]. Однако, как показали наши исследования [Котлер и др., 2015; Хромых и др., 2016, 2018а], дайки миролюбовского комплекса имеют другие вещественные характеристики и существенно моложе (280-270 млн лет [Хромых и др., 2018a; Khromykh et al., 2019]). Возрастным аналогом базитовых даек северовосточного простирания в Калба-Нарымской зоне являются массивы габбро прииртышского комплекса (317-313 млн лет) [Хромых и др., 2018б].

Геодинамические обстановки в процессе эволюции Обь-Зайсанской складчатой системы менялись от океанических и окраинно-континентальных к аккреционно-коллизионным и постколлизионным [3оненшайн и др., 1990; Щерба и др., 1998; Хаин, 2001; Владимиров и др., 2003, 2008]. В раннем карбоне на позиции Жарма-Саурской зоны происходило активное взаимодействие литосферы Обь-Засайнского океанического бассейна с Чингизской окраиной Казахстанского континента. Это выразилось в формировании пояса вулканогенных и вулканогенноосадочных отложений (базальты, андезибазальты, андезиты, туфы, граувакковые песчаники и алевролиты) турне-визейского возраста [Геологическая... 1976; Щерба и др., 1998].

К концу раннего карбона вулканическая деятельность стала затухать, фиксируются отдельные проявления андезитового и андезит-базальтового вулканизма в Чарской структурно-формационной зоне [Ермолов и др., 1983; Safonova et al., 2018]. Отложения серпуховского яруса на территории Восточного Казахстана представлены мелководными осадками терригенной природы, очевидно, эти осадки - продукты размыва ранее сформированных вулканических толщ. На территории Жарма-Саурской зоны осадки серпуховского яруса не встречаются, следовательно, к концу раннего карбона эта территория представляла собой окраину Казахстанского континента, восточная часть которой (Жарминская подзона) была сложена новообразованными вулканогенными и осадочными толщами. Магматизм саурской серии проявился в интервале 332-324 млн лет, что соответствует серпуховскому ярусу. Основываясь на корреляции геологических, петрологических и геохронологических данных, мы предполагаем, что габбро-гранитная саурская интрузивная серия была сформирована в геодинамической обстановке субдукции океанической литосферы Обь-Зайсанского бассейна под новообразованную кору окраины Казахстанского континента.

Полное закрытие океанического бассейна произошло в конце раннего карбона, а осадочные отложения среднего-верхнего карбона на территории Восточного Казахстана проявлены в отдельных грабенах или мульдах и представлены вулканогенно- 
осадочными континентальными молассовыми отложениями с базальными конгломератами [Ермолов и др., 1977, 1983; Зоненшайн и др., 1990; Щерба и др., 1998]. Формирование отдельных изолированных прогибов и впадин вместе с полным отсутствием морских осадков этого возраста позволяет предполагать воздымание, обусловленное, вероятно, формированием орогенного (коллизионного) сооружения. Возраст орогении может быть оценен как конец раннего - начало среднего карбона ( 320 млн лет). Начиная с этого времени рассматриваемая территория развивалась в континентальном режиме.

На всех стадиях развития Алтайской коллизионной системы важную структурообразующую роль играли сдвиговые перемещения отдельных блоков, обусловленные косым режимом коллизии континентов [Зоненшайин и др., 1990; Владимиров и др., 2003; Буслов и др., 2003; Буслов, 2011]. Важнейшими сдвиговыми разломами являются Жарминский, Чарский, Калба-Нарымский, Иртышский, движения вдоль которых продолжались на всех стадиях эволюции орогенного сооружения - от сокращения океанических пространств до посторогенических событий [Буслов и др., 2003; Владимиров и др., 2008].

Дайки северо-восточного простирания, изученные нами в Жарма-Саурской зоне, по возрасту (315 млн лет) являются синколлизионными и соответствуют времени существования орогенного сооружения. Их проявление является следствием раскалывания литосферы, очевидно, в результате сдвиговых смещений по структуро-определяющим Жарминскому и Жанан-Бугазскому разломам. При этом в процессы магмогенерации вероятно были вовлечены более глубинные и менее деплетированные области мантии - базитовые породы даек обогащены по ряду индикаторных элементов по сравнению с предшествующими базитовыми породами саурского комплекса. Синхронный (317-313 млн лет) базитовый магматизм, связанный со сдвиговыми движениями в Иртышской зоне, недавно описан на примере цепочки габброидных массивов Прииртышского комплекса [Хромых и др., 2018б; Khromykh et al., в печати]. Следовательно, масштабные сдвиговые деформации на уровне 317-313 млн лет (граница башкирского и московского ярусов карбона), сопряженные с базитовым магматизмом, могут свидетельствовать о прекращении режима сжатия. Примеры синметамофического и синколлизионного базитового магматизма как инди- катора начала коллапса орогена описаны для Ольхонской коллизионной системы каледонид в Западном Прибайкалье [Скляров и др., 2001; Федоровский, Скляров, 2010]. Аналогично изученные нами дайки северо-восточного простирания могут свидетельствовать о начале процессов растяжения.

\section{Выводы}

1. В Жарма-Саурской зоне в конце раннего карбона была проявлена саурская габбро-гранитоидная интрузивная серия, сформированная в геодинамической обстановке субдукции под новообразованную континентальную окраину.

2. В составе саурской серии целесообразно рассматривать: а) габбро-диориты саурского комплекса ( 330 млн лет), сформированные при эволюции базитовых магм, возникших в результате частичного плавления обводненной деплетированной мантии над зоной субдукции; б) гранитоиды бугазского комплекса ( 327 млн лет), магмы которых возникли при частичном плавлении вулканогенно-осадочных субстратов под воздействием базитовых магм.

3. Дайки северо-восточного простирания в Жарма-Саурской зоне имеют среднекарбоновый возраст (315 млн лет) и проявились в результате разрывов сплошности литосферы орогенного сооружения при сдвиговых движениях по глубинным разломам.

4. Базитовые магмы, образовавшие дайки северовосточного простирания, характеризуются относительно обогащенным составом, что свидетельствует о другом составе мантийного источника, вероятно более глубинных гранатовых перидотитов.

Авторы благодарят д-ра геол.-минерал. наук Е.М. Сапаргалиева и канд. геол.-минерал. наук И.Ю. Сафонову за содействие и помощь в экспедиционных исследованиях, канд. геол.-минерал. наук Н.Г. Карманову и канд. хим. наук И.В. Николаеву (ЦКП МИИ ИГМ СО РАН, г. Новосибирск) за аналитические исследования состава пород, д-ра геол.минерал. наук Т.Б. Баянову (ГИ КНЦ РАН, г. Апатиты) - за выполненные изотопные исследования Nd. Работа выполнена по государственным заданиям ИГМ СО РАН, при поддержке Министерства науки и высшего образования РФ (проект № 5.1688.2017/4.6, проект № 14.Y26.31.0018), РФФИ (проект № 17-05-00825).

\section{ЛИТЕРАТУРА}

Буслов М.М., Ватанабе Т., Смирнова Л.В., Фудживара И., Ивата К., Де Граве И., Семаков Н.Н., Травин А.В., Кирьянова А.П., Кох Д.А. Роль сдвигов в позднепалеозойско-раннемезозойской тектонике и геодинамике Алтае-Саянской и Восточно-Казахстанской складчатых областей // Геология и геофизика. 2003. Т. 44, № 1-2. С. 49-75.

Буслов М.М. Тектоника и геодинамика Центрально-Азиатского складчатого пояса: роль позднепалеозойских крупноамплитудных сдвигов // Геология и геофизика. 2011. Т. 52, № 1. С. 66-90.

Владимиров А.Г., Крук Н.Н., Руднев С.Н., Хромых С.В. Геодинамика и гранитоидный магматизм коллизионных орогенов // Геология и геофизика. 2003. Т. 44, № 12. С. 1321-1338. 
Владимиров А.Г., Крук Н.Н., Хромых С.В., Полянский О.П., Червов В.В., Владимиров В.Г., Травин А.В., Бабин Г.А., Куйбида М.Л., Хомяков В.Д. Пермский магматизм и деформации литосферы Алтая как следствие термических процессов в земной коре и мантии // Геология и геофизика. 2008. Т. 49, № 7. С. 621-636.

Владимиров А.Г., Изох А.Э., Поляков Г.В., Бабин Г.А., Мехоношин А.С., Крук Н.Н., Хлестов В.В., Хромых С.В., Травин А.В., Юдин Д.С., Шелепаев Р.А., Кармышева И.В., Михеев Е.И. Габбро-гранитные интрузивные серии и их индикаторное значение для геодинамических реконструкций // Петрология. 2013. Т. 21, № 2. С. 177-201.

Дегтярев К.Е. Тектоническая эволюция раннепалеозойских островодужных систем и формирование континентальной коры каледонид Казахстана. М. : ГЕОС, 2012. 289 с.

Ермолов П.В., Изох Э.П., Пономарёва А.П., Тян В.Д. Габбро-гранитные серии западной части Зайсанской складчатой системы. Новосибирск : Наука, 1977. 246 с.

Ермолов П.В., Владимиров А.Г., Изох А.Э., Полянский Н.В., Кузебный В.С., Ревякин П.С., Борцов В.Д. Орогенный магматизм офиолитовых поясов (на примере Восточного Казахстана). Новосибирск : Наука, 1983. 191 с.

Зоненшайн Л.П., Кузьмин М.И., Натапов Л.М. Тектоника литосферных плит территории СССР. М. : Недра, 1990. Кн. 1. 327 с.; Кн. 2.336 с. $234 \mathrm{c}$.

Короновский Н.В., Демина Л.И. Магматизм как индикатор геодинамических обстановок : учеб. пособие. М. : МГУ, 2011.

Котлер П.Д., Хромых С.В., Владимиров А.Г., Навозов О.В., Травин А.В., Караваева Г.С., Крук Н.Н., Мурзинцев Н.Г. Новые данные о возрасте и геодинамическая интерпретация гранитоидов Калба-Нарымского батолита (Восточный Казахстан) // Доклады Академии наук. 2015. Т. 462, № 5. С. 572-577.

Крук Н.Н. Континентальная кора Горного Алтая: этапы формирования и эволюции, индикаторная роль гранитоидов // Геология и геофизика. 2015. Т. 56, № 8. С. 1403-1423.

Кузнецов Ю.А. Главные типы магматических формаций. М. : Недра, 1964. 387 с.

Лопатников В.В., Изох Э.П., Ермолов П.В., Пономарева А.П., Степанов А.С. Магматизм и рудоносность КалбаНарымской зоны Восточного Казахстана. М. : Наука, 1982. 248 с.

Магматические горные породы. Т. 1: Классификация, номенклатура, петрография / под ред. О.А. Богатикова. М. : Наука, $1983.370 \mathrm{c}$.

Тектоническая карта Алтая. Масштаб 1:1000000 / ред. В.П. Нехорошев. ВСЕГЕИ, 1963.

Скляров Е.В., Федоровский В.С., Гладкочуб Д.П., Владимиров А.Г. Синметаморфические базитовые дайки - индикаторы коллапса коллизионной структуры Западного Прибайкалья // Доклады РАН. 2001. Т. 381, № 4. С. $522-527$.

Федоровский В.С., Скляров Е.В. Ольхонский геодинамический полигон (Байкал): аэрокосмические данные высокого разрешения и геологические карты нового поколения // Геодинамика и тектонофизика. 2010. Т. 1, № 4. С. 331-418.

Фролова Т.И., Бурикова И.А. Магматические формации современных геотектонических обстановок : учеб. пособие. М. : Изд-во МГУ, 1997. 320 с.

Хаин В.Е. Тектоника континентов и океанов. М. : Научный мир, 2001. 606 с.

Хромых С.В., Цыганков А.А., Котлер П.Д., Навозов О.В., Крук Н.Н., Владимиров А.Г., Травин А.В., Юдин Д.С., Бурмакина Г.Н., Хубанов В.Б., Буянтуев М.Д., Анциферова Т.Н., Караваева Г.С. Позднепалеозойский гранитоидный магматизм Восточного Казахстана и Западного Забайкалья: тестирование плюмовой модели // Геология и геофизика. 2016. Т. 57, № 5. C. $983-1004$.

Хромых С.В., Котлер П.Д., Гурова А.В., Семенова Д.В. Посторогенные дайковые пояса Алтайской аккреционноколлизионной системы: геологическая позиция, состав и возраст // Корреляция алтаид и уралид: глубинное строение литосферы, стратиграфия, магматизм, метаморфизм, геодинамика и металлогения : материалы Четвертой междунар. науч. конф. 26 апреля 2018 г. Новосибирск : Изд-во СО РАН, 2018а. С. 161-162.

Хромых С.В., Гурова А.В., Изох А.Э. Петрология и геохимия габброидов Суровско-Таловского дифференцированного интрузива (Иртышская сдвиговая зона, Восточный Казахстан) // Рудно-магматические системы. Магматизм, металлогения и тектоника Северной Азии : сб. науч. тр. по фундаментальным исследованиям Института геологии и минералогии СО РАН. Новосибирск : ИГМ СО РАН, 2018б. Вып. 1. С. 5-25.

Хубанов В.Б., Буянтуев М.Д., Цыганков А.А. U-Pb изотопное датирование цирконов из PZ3-MZ магматических комплексов Забайкалья методом магнитно-секторной масс-спектрометрии с лазерным пробоотбором: процедура определения и сопоставление с SHRIMP данными // Геология и геофизика. 2016. Т. 57, № 1. С. 241-258.

Геологическая карта Казахской СССР. Масштаб 1:500000. Восточно-Казахстанская серия / глав. ред. С.Е. Чакабаев. Министерство геологии Казахской СССР, 1976.

Щерба Г.Н., Дьячков Б.А., Нахтигаль Г.П. Жарма-Саурский геотектоноген. Алма-Ата : Наука, 1976. 200 с.

Щерба Г.Н., Дьячков Б.А., Стучевский Н.И., Нахтигаль Г.П., Антоненко А.Н., Любецкий В.Н. Большой Алтай (геология и металлогения). Кн. 1. Геологическое строение. Алматы : Гылым, 1998. 304 с.

Ярмолюк В.В., Коваленко В.И. Глубинная геодинамика, мантийные плюмы и их роль в формировании ЦентральноАзиатского складчатого пояса // Петрология. 2003. Т. 11, № 6. С. 556-586.

Ярмолюк В.В., Ковач В.П., Коваленко В.И., Сальникова Е.Б., Козловский А.М., Котов А.Б., Яковлева С.З., Федосеенко А.М. Состав, источники и механизмы формирования континентальной коры Озерной зоны каледонид Центральной Азии: I. Геологические и геохронологические данные // Петрология. 2011. T. 19, № 1. С. 56-79.

Griffin W.L., Powell W.J., Pearson N.J., O'Reilly S.Y. GLITTER: Data reduction software for laser ablation ICP-MS // Sylvester P. (ed.). Laser Ablation ICP-MS in the Earth Sciences: Current practices and outstanding issues: Mineralogical Association of Canada, Short Course Series. 2008. 40. P. 307-311.

Khromykh S.V., Kotler P.D., Izokh A.E., Kruk N.N. A review of Early Permian (300-270 Ma) magmatism in Eastern Kazakhstan and implications for plate tectonics and plume interplay // Geodynamics \& Tectonophysics. 2019. V. 10, is. 1. P. 79-99.

Khromykh S.V., Izokh A.E., Gurova A.V., Cherdantseva M.V., Savinsky I.A., Vishnevsky A.V. Syncollisional gabbro in the Irtysh shear zone, Eastern Kazakhstan: compositions, geochronology, and geodynamic implications // Lithos, в печати.

Lin J., Liu Y., Yang Y., Hu Zh. Calibration and correction of LA-ICP-MS amd LA-MC-ICP-MS analyses for element contents and isotopic ratios // Solid Earth Sciences. 2016. V. 1. P. 5-27. 
Ludwig K.R. Isoplot/Ex Version 3.00: a Geochronological Toolkit for Microsoft Excel. Berkeley, CA : Berkeley Geochronology Center, 2003.

Pearce J.A., Norry M.J. Petrogenetic implications of Ti, Zr, Y, and Nb variations in volcanic rocks // Contrib Mineral Petrol. 1979. V. 69. P. 33-47.

Pearce J.A. Trace element characteristics of lavas from destructive plate boundaries // Thorpe R.S. (ed). Andesites: Orogenic Andesites and Related Rocks. John Wiley \& Sons, Chichester. 1982. P. 525-548.

Pearce J.A., Harris N.W., Tindle A.G. Trace element discrimination diagrams for the tectonic interpretation of granitic rocks // Journal of Petrology. 1984. V. 25. P. 956-983.

Pearce J.A. Geochemical fingerprinting of oceanic basalts with applications to ophiolite classification and the search for Archean oceanic crust // Lithos. 2008. V. 100. P. 14-48.

Safonova I., Komiya T., Romer R.L., Simonov V., Seltmann R., Rudnev S., Yamamoto S., Sun M. Supra-subduction igneous formations of the Char ophiolite belt, East Kazakhstan // Gondwana Research. 2018. V. 59. P. 159-179.

Schandl E.S., Gorton M.P. Application of high field strength elements to discriminate tectonic settings in VMS environments // Economic Geology. 2002. V. 97. P. 629-642.

Sun S.-s., McDonough W.F. Chemical and isotopic systematics of oceanic basalts: implications for mantle composition and processes // Geological Society, London, Special Publications. 1989. P. 42. P. 313-345.

Windley B.F., Alexeiev D., Xiao W., Kröner A., Badarch G. Tectonic models for accretion of the Central Asian Orogenic Belt // Journal of the Geological Society. 2007. V. 164. P. 31-47.

Yang G., Li Y., Safonova I., Yi S., Tong L., Seltmann R. Early Carboniferous volcanic rocks of West Junggar in the western Central Asian Orogenic Belt: implications for a supra-subduction system // International Geology Review. 2014. V. 56. P. $823-844$.

\title{
Авторы:
}

Хромых Сергей Владимирович, кандидат геолого-минералогических наук, старший научный сотрудник, лаборатория петрологии и рудоносности магматических формаций, Институт геологии и минералогии им. В.С. Соболева СО РАН, Новосибирский государственный университет, Новосибирск, Россия.

E-mail: serkhrom@mail.ru

Котлер Павел Дмитриевич, младший научный сотрудник, лаборатория петрологии и рудоносности магматических формаций, Институт геологии и минералогии им. В.С. Соболева СО РАН, Новосибирский государственный университет, Новосибирск, Россия.

E-mail: pkotler@yandex.ru

Семенова Дина Валерьевна, научный сотрудник, лаборатория изотопно-аналитической геохимии, Институт геологии и минералогии им. В.С. Соболева СО РАН, Новосибирск, Россия.

E-mail: sediva@igm.nsc.ru

Geosphere Research, 2019, 2, 6-26. DOI: 10.17223/25421379/11/1

\author{
Khromykh S.V. ${ }^{1,2}$, Kotler P.D. ${ }^{1,2}$, Semenova D.V. ${ }^{1}$ \\ ${ }^{I}$ V.S. Sobolev Institute of Geology and Mineralogy SB RAS, Novosibirsk, Russia \\ ${ }^{2}$ Novosibirsk State University, Novosibirsk, Russia
}

\section{GEOCHEMISTRY, AGE AND GEODYNAMIC SETTINGS FOR SAUR GABBRO-GRANITE INTRUSIVE SERIES, EASTERN KAZAKHSTAN}

The territory of East Kazakhstan is part of the Altai collision system formed in the Late Paleozoic during the collision of the Siberian and Kazakhstan continents and the closure of the Ob-Zaisan paleooceanic basin. In the Early Carboniferous, in the Zharma-Saur zone, the Ob-Zaisan basin interacted with the active margin of the Kazakhstan continent. The formation of volcanic and intrusive associations was the result of these processes.

The article presents the results of geochemical and geochronological studies of gabbro, granite and mafic dikes of the Zharma-Saur zone, Eastern Kazakhstan. It was established that gabbro-diorite-granite Saur intrusive series was formed 330-327 Ma in the geodynamic environment of subduction under the newly formed continental margin of the Kazakhstan continent. Gabbro and diorites were formed during the evolution of basic magmas resulting from the partial melting of the water-saturated depleted mantle over the subduction zone. Granite magmas were formed during the partial melting of volcanogenic-sedimentary substrates under the influence of basic magmas.

For the first time, the age and geochemical features of dikes of the north-east strike in the Zharma-Saur zone are determined. They have a Middle Carboniferous age (315 Ma) and manifested as a result of break-offs in the lithosphere of the orogenic structure during shear movements along deep faults. Mafic dikes are characterized by a relatively enriched geochemical composition, which indicates another mantle source.

Keywords: gabbro-granite intrusive series, accretion-collision systems, Eastern Kazakhstan, Central Asia.

\section{References}

Buslov M.M., Watanabe T., Smirnova L.V., Fujiwara I., Iwata K., de Grave I., Semakov N.N., Travin A.V., Kir'yanova A.P., Kokh D.A. Role of strike-slip faults in Late Paleozoic-Early Mesozoic tectonics and geodynamics of the Altai-Sayan and East Kazakhstan folded zone // Russian Geology and Geophysics. 2003. V. 44. Iss. 1-2. pp. 47-71.

Buslov M.M. Tectonics and geodynamics of the Central Asian Foldbelt: The role of Late Paleozoic large-amplitude strike-slip faults // Russian Geology and Geophysics. 2011. V. 52. Iss. 1. pp. 52-71.

Vladimirov A.G., Kruk N.N., Rudnev S.N., Khromykh S.V., Geodynamics and granitoid magmatism of collision orogen // Geologiya i Geofizika (Russian Geology and Geophysics). 2003. V. 44. Iss. 12. pp. 1321-1338. 
Vladimirov A.G., Kruk N.N., Khromykh S.V., Polyansky O.P., Chervov V.V., Vladimirov V.G., Travin A.V., Babin G.A., Kuibida M.L., Khomyakov V.D. Permian magmatism and lithospheric deformation in the Altai caused by crustal and mantle thermal processes // Russian Geology and Geophysics. 2008. V. 49. Iss. 7. pp. 468-479.

Vladimirov A.G., Izokh A.E., Polyakov G.V., Babin G.A., Mekhonoshin A.S., Kruk N.N., Khlestov V.V., Khromykh S.V., Travin A.V., Yudin D.S., Shelepaev R.A., Karmysheva I.V., Mikheev E.I. Gabbro-granite intrusive series and their indicator importance for geodynamic reconstructions // Petrology. 2013. V. 21. Iss. 2. pp. 158-180.

Degtyarev K.E. Tektonicheskaya evolyutsiya rannepaleozoiskih ostrovoduzhnyh sistem I formirovanie kontinentalnoi kory kaledonid Kazakhstana [Tectonic evolution of the Early Paleozoic island arcs and continental crust formation in Caledonides of Kazakhstan]. Moscow. GEOS. 2012. 289 p. In Russian.

Ermolov P.V., Izokh E.P., Ponomareva A.P., Tyan V.D. Gabbro-granitnye serii zapadnoi chasti Zaisanskoi skladchatoi sistemy [Gabbro-Granitic Rocks in the Western Zaisan Orogenic System]. Novosibirsk, Nauka, 1977. 246 p. In Russian.

Ermolov P.V., Vladimirov A.G., Izokh A.E., Polyansky N.V., Kuzebny V.S., Revyakin P.S., Bortsov V.D. Orogennyi magmatism ofiolitovyh poyasov (na primereVostochnogo Kazakhstana) [Orogenic Magmatism of Ophiolitic Belts (on the Example of East Kazakhstan)]. Novosibirsk, Nauka, 1983. 206 p. In Russian.

Zonenshain L.P., Kuzmin M.I., Natapov L.M., Geology of the USSR: A Plate Tectonic Synthesis. Geodynamic Series. 1990. V. 21. American Geophysical Union, Washington D. C., 242 pp.

Koronovsky N.V., Demina L.I. Magmatism kak indikator geodinamicheskih obstanovok [Magmatismas indicator of geodynamic settings]. Moscow. MSU, 2011. 234 p. In Russian.

Kotler P.D., Khromykh S.V., Vladimirov A.G., Navozov O.V., Travin A.V., Karavaeva G.S., Kruk N.N., Murzintsev N.G. New data on the age and geodynamic interpretation of the Kalba-Narym granitic batholith, eastern Kazakhstan // Doklady Earth Sciences. 2015. V. 462. Iss. 2. pp. 565-569.

Kruk N.N. Continental crust of Gorny Altai: stages of formation and evolution; indicative role of granitoids // Russian Geology and Geophysics. 2015. V. 56. Iss. 8. pp. 1097-1113.

Kuznetsov Yu.A. Glavnye tipymagmaticheskih formatsiy [Main types ofigneous formations]. Moscow, Nedra, 1964. 387 p.

Lopatnikov V.V., Izokh E.P., Ermolov P.V., Ponomareva A.P., Stepanov A.S. Magmatism I rudonosnost Kalba-Narymskoi zony Vostochnogo Kazakhstana [Magmatism and Metallogeny of the Kalba-Narym Zone, Eastern Kazakhstan]. Moscow. Nauka, 1982.248 p. In Russian.

Magmaticheskie gornye porody. Tom 1. Klassifikatsiya, nomenklatura, petrografiya [Igneous rocks. Vol. 1. Classofication and Petrography]. Bogatikov O.A. (Ed.). Moscow : Nauka, 1983. 370 p. In Russian.

Tektonicgeskaya karta Altaiya. Masshtab 1:1000000 Nekhoroshev V.P. (Ed.) [Tectonic map of Altai. Scale 1:1000000]. VSEGEI. 1963. In Russian.

Sklyarov E.V., Fedorovskiy V.S., Gladkochub D.P., Vladimirov A.G., The synmetamorphic basic dykes - indicators of the collapse of the Western Cisbaikalia collisional structure // Doklady Earth Sciences. 2001. V. 381. Iss. 4. pp. 522-528.

Fedorovskiy V.S., Sklyarov E.V., The Olkhon geodynamic test ground (Lake Baikal): high resolution satellite data and geological maps of new generation // Geodynamics \& Tectonophysics. 2010. V. 1. Iss. 4. pp. 331-418.

Frolova T.I., Burikova I.A. Magmaticheskie formacii sovremennyh geotektonicheskih obstanovok [Igneous formations of modern geodynamic settings]. Moscow, MSU, 1997. 320 p. In Russian

Khain V.E. Tektonika kontinentov i okeanov (god 2000) [Tectonics of continents and oceans (2000 year)]. Moscow, Nauchnyi Mir, 2001. 606 p. In Russian

Khromykh S.V., Tsygankov A.A., Kotler P.D., Navozov O.V., Kruk N.N., Vladimirov A.G., Travin A.V., Yudin D.S., Burmakina G.N., Khubanov V.B., Buyantuev M.D., Antsiferova T.N., Karavaeva G.S. Late Paleozoic granitoid magmatism of Eastern Kazakhstan and Western Transbaikalia: Plume model test // Russian Geology and Geophysics. 2016. V. 57. Iss. 5. pp. 773-789.

Khromykh S.V., Kotler P.D., Gurova A.V., Semenova D.V. Postorogennye daikovye poyasa Altaiskoi akretcionno-collizionnoi sistemy: geologicheskaya pozitsiya, sostav $i$ vozrast [Post-orogenic dikebelta in Altai collision system: geological position, composition and age] // Correlation of Altaidesand Uralides. Abstracts of IV International scientific conference. Novosibirsk. 2018a. pp. 161-162. In Russian

Khromykh S.V., Gurova A.V., Izokh A.E. Petrologiya i geokhimiya gabbroidov Surovsko-Talovskogo differentsirovannogo intruziva (Irtyshskaya sdvigovaya zona, Vostochnyi Kazakhstan) [Petrology and geokhemistry of gabbro in Surovo-Talovka differentiated intrusion (Irtysh shear zone, Eastern Kazakhstan)]. Ore-magmetic systems. Magmatism, metallogeny and tectonics of Northern Asia. Transactions of the Institute of Geology and Mineralogy SB RAS. Novosibirsk. 2018b. pp. 5-25. In Russian.

Khubanov V.B., Buyantuev M.D., Tsygankov A.A. U-Pb dating of zircons from PZ3-MZ igneous complexes of Transbaikalia by sector-field mass spectrometry with laser sampling: technique and comparison with SHRIMP // Russian Geology and Geophysics. 2016. V. 57. Iss. 1. pp. 190-205.

Geologicheskaya karta Kazakhskoi SSR. Masshtab 1:500000. Vostochno-Kazakhstanskaya seriya [Geological map of Kazakh SSR. Chakabaev S.E. (Ed.) Scale 1:500000. Eastern Kazakhstan]. Ministry of Geology of Kazakh SSR. 1976.

Shcherba G.N., D'yachkov B.A., Nakhtigal G.P., Zharma-Saurskyi geotektonogen [The Zharma-Saur Metallogenic Belt]. Alma-Ata, Nauka, 1976. 200 p. In Russian.

Shcherba G.N., D'yachkov B.A., Stuchevsky N.I., Nakhtigal G.P., Antonenko A.N., Lubetsky V.N. Bolshoi Altai (geologiya i metallogeniya) [Great Altai (Geology and Metallogeny). Book 1. Geological Structure]. Almaty, Gylym, 304 p. In Russian.

Yarmolyuk V.V., Kovalenko V.I. Deep geodynamics and mantle plumes: their role in the formation of the Central Asian fold belt // Petrology. 2003. V. 11. Iss. 6. pp. 504-531.

Yarmolyuk V.V., Kovalenko V.I., Kozlovskii A.M., Kovach V.P., Salnikova E.B., Kotov A.B., Yakovleva S.Z., Fedoseenko A.M. Composition, sources, and mechanism of continental crust growth in the Lake zone of the Central Asian Caledonides: I. Geological and geochronological data // Petrology. 2011. V. 19. Iss. 1. pp. 55-78.

Griffin W.L., Powell W.J., Pearson N.J., O'Reilly S.Y. GLITTER: Data reduction software for laser ablation ICP-MS // in Sylvester P. (ed.), Laser Ablation ICP-MS in the Earth Sciences: Current practices and outstanding issues: Mineralogical Association of Canada, Short Course Series, 2008. 40, pp. 307-311.

Khromykh S.V., Kotler P.D., Izokh A.E., Kruk N.N. A review of Early Permian (300-270 Ma) magmatism in Eastern Kazakhstan and implications for plate tectonics and plume interplay// Geodynamics \& Tectonophysics. 2019. V. 10. Iss 1. pp. 79-99. 
Khromykh S.V., Izokh A.E., Gurova A.V., Cherdantseva M.V., Savinsky I.A., Vishnevsky A.V. Syncollisional gabbro in the Irtysh shear zone, Eastern Kazakhstan: compositions, geochronology, and geodynamic implications // Lithos, in press.

Lin J., Liu Y., Yang Y., Hu Zh. Calibration and correction of LA-ICP-MS amd LA-MC-ICP-MS analyses for element contents and isotopic ratios // Solid Earth Sciences. 2016. V. 1. pp. 5-27.

Ludwig K.R. Isoplot/Ex Version 3.00: a Geochronological Toolkit for Microsoft Excel. Berkeley, CA. Berkeley Geochronology Center, 2003.

Pearce J.A., Norry M.J. Petrogenetic implications of Ti, Zr, Y, and Nb variations in volcanic rocks // Contrib Mineral Petrol. 1979. V. 69. pp. 33-47.

Pearce J.A. Trace element characteristics of lavas from destructive plate boundaries // Thorpe R.S. (ed). Andesites: Orogenic Andesites and Related Rocks. John Wiley \& Sons, Chichester. 1982. pp. 525-548.

Pearce J.A., Harris N.W., Tindle A.G. Trace element discrimination diagrams for the tectonic interpretation of granitic rocks // Journal of Petrology. 1984. V. 25. pp. 956-983.

Pearce J.A. Geochemical fingerprinting of oceanic basalts with applications to ophiolite classification and the search for Archean oceanic crust // Lithos. 2008. V. 100. pp. 14-48.

Safonova I., Komiya T., Romer R.L., Simonov V., Seltmann R., Rudnev S., Yamamoto S., Sun M. Supra-subduction igneous formations of the Char ophiolite belt, East Kazakhstan // Gondwana Research. 2018. V. 59. pp. 159-179.

Schandl E.S., Gorton M.P. Application of high field strength elements to discriminate tectonic settings in VMS environments // Economic Geology. 2002. V. 97. pp. 629-642.

Sun S.-s., McDonough W.F. Chemical and isotopic systematics of oceanic basalts: implications for mantle composition and processes // Geological Society, London, Special Publications. 1989. V. 42. pp. 313-345.

Windley B.F., Alexeiev D., Xiao W., Kröner A., Badarch G. Tectonic models for accretion of the Central Asian Orogenic Belt // Journal of the Geological Society. 2007. V. 164. pp. 31-47.

Yang G., Li Y., Safonova I., Yi S., Tong L., Seltmann R. Early Carboniferous volcanic rocks of West Junggar in the western Central Asian Orogenic Belt: implications for a supra-subduction system // International Geology Review. 2014. V. 56. pp. 823-844.

\section{Authors:}

Khromykh Sergey V., Cand. Sci. (Geol.-Miner.), Senior Scientific Researcher, V.S. Sobolev Institute of Geology and Mineralogy SB RAS, Assistant Professor, Department of Mineralogy and Petrography, Novosibirsk State University, Novosibirsk, Russia.

E-mail: serkhrom@mail.ru

Kotler Pavel D., Researcher, V.S. Sobolev Institute of Geology and Mineralogy SB RAS, Novosibirsk State University; Novosibirsk, Russia.

E-mail: pkotler@yandex.ru

Semenova Dina V., Cand. Sci. (Geol.-Miner.), Researcher, V.S. Sobolev Institute of Geology and Mineralogy SB RAS, Novosibirsk, Russia.

E-mail: sediva@igm.nsc.ru 